\section{OAK RIDGE NATIONAL LABORATORY}

\section{UNION \\ CARBIDE}

ORNL/SUb--7327/13

DE82 009939

Corrosion Studies in Fuel Element Reprocessing Environments Containing Nitric Acid
J. A. Beavers

W. E. Berry

J. C. Griess

R. R. White

OPERATED BY

UNION CARBIDE CORPORATION FOR THE UNITED STATES DEPARTMENT OF ENERGY 


\section{Printed in the United States of America. Available from}

National Technical Information Service

U.S. Department of Commerce

5285 Port Royal Road, Springfield, Virginia 22161

NTIS price codes-Printed Copy:A03 Microfiche A01

This report was prepared as an account of work sponsored by an agency of the United States Government. Neither the United States Government nor any agency thereof, nor any of their employees, makes any warranty, express or implied, or assumes any legal liability or responsibility for the accuracy, completeness, or usefulness of any information, apparatus, product, or process disclosed, or represents that its use would not infringe privately owned rights. Reference herein to any specific commercial product, process, or service by trade name, trademark, manufacturer, or otherwise, does not necessarily constitute or imply its endorsement, recommendation, or favoring by the United States Government or any agency thereof. The views and opinions of authors expressed herein do not necessarily state or reflect those of the United States Government or any agency thereof. 


\section{DISCLAIMER}

This report was prepared as an account of work sponsored by an agency of the United States Government. Neither the United States Government nor any agency Thereof, nor any of their employees, makes any warranty, express or implied, or assumes any legal liability or responsibility for the accuracy, completeness, or usefulness of any information, apparatus, product, or process disclosed, or represents that its use would not infringe privately owned rights. Reference herein to any specific commercial product, process, or service by trade name, trademark, manufacturer, or otherwise does not necessarily constitute or imply its endorsement, recommendation, or favoring by the United States Government or any agency thereof. The views and opinions of authors expressed herein do not necessarily state or reflect those of the United States Government or any agency thereof. 


\section{DISCLAIMER}

Portions of this document may be illegible in electronic image products. Images are produced from the best available original document. 
ORNL/Sub-7327/13

Dist. Category UC-86

Contract No. W-7405-eng-26

Consolidated Fuel Reprocessing Program

\title{
CORROSION STUDIES IN FUEL ELEMENT REPROCESSING ENVIRONMENTS CONTAINING NITRIC ACID
}

\author{
J. A. Beavers, R. R. White, and W. E. Berry \\ Battelle-Columbus Laboratories \\ Columbus, Ohio \\ J. C. Griess \\ Metals and Ceramics Division \\ Oak Ridge National Laboratory
}

Date Published: ApriI 1982

Under Subcontract 7327

for

OAK RIDGE NATIONAL LABORATORY

Oak Ridge, Tennessee 37830

operated by

UNION CARBIDE CORPORATION

for the

DEPARTMENT OF ENERGY 


\section{CONTENTS}

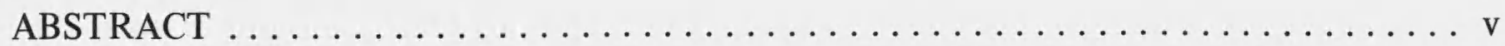

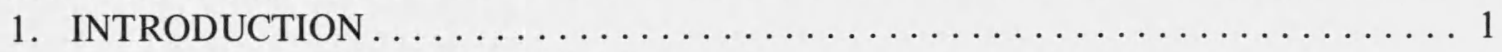

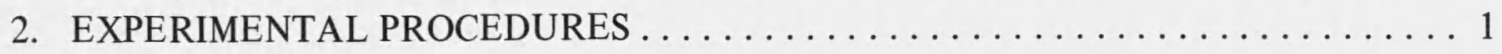

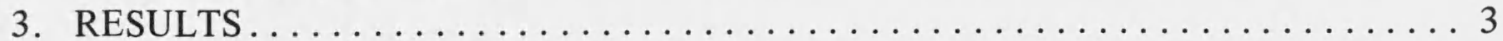

3.1 Corrosion of Titanium in Nitric Acid $\ldots \ldots \ldots \ldots \ldots \ldots \ldots \ldots \ldots \ldots \ldots \ldots \ldots \ldots \ldots \ldots$

3.2 Corrosion of Inconel 690 and 671 in Nitric

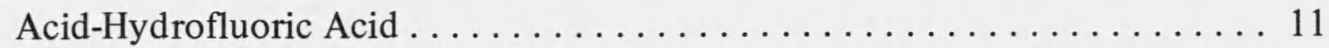

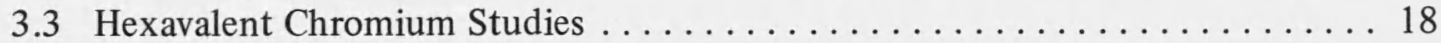

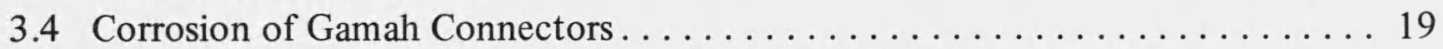

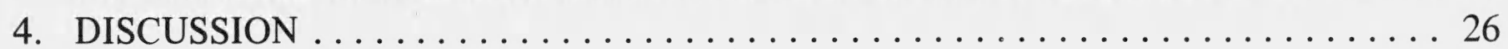

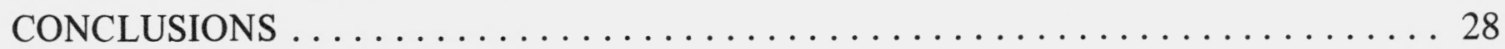

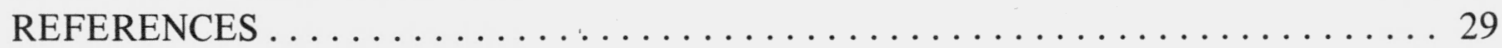




\section{INTRODUCTION}

Although nitric acid has been used extensively in the processing of spent nuclear reactor fuel elements, a method of processing fast reactor fuels being developed by the Consolidated Fuel Reprocessing Program involves the use of nitric acid in ways not previously encountered in reprocessing plants. For example, the fuel will be dissolved in nitric acid in a continuous rotary dissolver, and plutonium-containing residues from this dissolver may be dissolved in a nitric acid-hydrofluoric acid solution in a separate vessel. The component parts of the plant will be joined with mechanical connectors that expose the ends of pipes and crevices to nitric acid solutions. In addition, gaseous iodine will be converted to nonvolatile iodic acid in hyperazeotropic nitric acid (Iodox process), which will be produced in the plant by reacting dilute nitric acid with hot concentrated magnesium nitrate solutions. Consequently, an experimental program was necessary to select the most appropriate materials for use in this processing scheme.

This report describes part of the experimental work in nitric acid solutions completed at Battelle-Columbus Laboratories under subcontract with Oak Ridge National Laboratory. A previous report ${ }^{1}$ gave detailed results obtained in hyperazeotropic nitric acid under conditions that will exist in the Iodox process. The present report contains additional experimental results relevant to corrosion of the equipment. The results obtained in nitric acid-hydrofluoric acid solutions that may be used in a secondary dissolver are included, and preliminary results on the behavior of a type of mechanical pipe connector (Gamah*) are

also presented. ${ }^{\dagger}$ In the absence of a radiation field, $\mathrm{Cr}$ (VI) ions can form in hot nitric acid solutions and strongly influence corrosion of stainless steel; therefore, brief studies were conducted on the rates of oxidation of $\mathrm{Cr}$ (III) to $\mathrm{Cr}(\mathrm{VI})$ in these solutions.

The presentation of the results in this report completes the Battelle commitment under the subcontract with ORNL. It should be pointed out that in most cases the results are preliminary in nature, and more thorough and longer-term testing needs to be conducted before final selection of materials for advanced fuel reprocessing plants can be made with confidence.

\section{EXPERIMENTAL PROCEDURES}

The experimental procedures used in this study were more or less conventional. Thus, the weight change specimens were made from flat plates that were abraded successively on Nos. 400 and $600 \mathrm{SiC}$, degreased in acetone, and weighed before exposure. Crevice corrosion specimens were flat plates treated in that same manner with serrated Teflon washers $(12.5-\mathrm{mm}$ diam) clamped on one surface. Each washer created 16 crevices separated from each other by similar size areas that had free access to the corrosive fluid. Anodized titanium specimens were prepared using a solution containing $170 \mathrm{~mL}$ of concentrated sulfuric acid per liter. The anodization was for 10 or $30 \mathrm{~min}$ at $18 \mathrm{~V}$.

*A division of Stanley Aviation Corporation.

$\dagger$ Metallographic examination of the connectors was conducted by the Metallography Laboratory at ORNL. 
Electrochemical studies were limited to titanium in nitric acid. Polarization resistance (PR) measurements were made by a previously described technique ${ }^{2}$ using cylindrical specimens that were abraded through No. $600 \mathrm{SiC}$. The surface area was $10 \mathrm{~mm}^{2}$. Two specimens were immersed in the test solution, and the PR was continuously determined by applying $10 \mathrm{mV}$ between the two and measuring the resultant current. The polarity of the specimens was reversed every $200 \mathrm{~s}$. Simultaneously, the potential of a platinum electrode was measured in the same solution relative to an external saturated calomel electrode (SCE) to measure changes in the oxidation potential of the solution.

The potentiostatic and potentiodynamic polarization behavior of titanium was studied in boiling nitric acid. Cylindrical specimens ( $4.8 \mathrm{~mm}$ diam and $12.5 \mathrm{~mm}$ long) were abraded through No. $600 \mathrm{SiC}$ and degreased in acetone. In the latter study the potential of the specimen was scanned in the noble direction at a rate of $10 \mathrm{mV} / \mathrm{min}$ starting at $0.7 \mathrm{~V}$ vs SCE, and the current flow between the specimen and platinum counter electrode was recorded. In the former study the potential of specimens was held constant at selected values between 0.7 and $1.1 \mathrm{~V}$ vs SCE, and the current flow between the specimen and the platinum electrode was measured over periods extending to $50 \mathrm{~h}$. The current generally stabilized after $25 \mathrm{~h}$, and the stable values were recorded.

All titanium specimens were made of commercially pure titanium.

Tests in nitric acid-hydrofluoric acid solution were performed in Teflon equipment using only Inconel 690 and 671 specimens. Welded specimens of both alloys were prepared by welding two strips of the annealed and quenched alloy (19-mm wide by $3.2-\mathrm{mm}$ thick) and machining the welded strips into $38 \times 12.7 \times 3.2 \mathrm{~mm}$ specimens with the weld parallel to the short dimension of the specimen. Inconel 690 specimens were welded with INCO filler metal 625, and the Inconel 671 specimens were welded with INCO filler metal 72. The welded specimens received no heat treatment after welding. Unwelded specimens of Inconel 671 were annealed at $1200^{\circ} \mathrm{C}$ for $2 \mathrm{~h}$, and half of them were air quenched; others were furnace-cooled.

The nominal composition of the two alloys and the weld filler metals is shown in Table 1.

Table 1. Nominal composition of alloys and weld filler metals tested in $8 \mathrm{M} \mathrm{HNO}_{3}-0.05 \mathrm{M}$ HF solution

\begin{tabular}{cccccc}
\hline \multirow{2}{*}{ Material } & \multicolumn{5}{c}{$\begin{array}{c}\text { Composition } \\
\text { (wt \%) }\end{array}$} \\
\cline { 2 - 6 } & $\mathrm{Ni}$ & $\mathrm{Cr}$ & $\mathrm{Fe}$ & $\mathrm{C}$ & Other \\
\hline Inconel 690 & 60 & 30 & 10 & 0.03 & \\
$\begin{array}{c}\text { Inconel 671 } \\
\begin{array}{c}\text { Inconel filler } \\
\text { metal 72 }\end{array}\end{array}$ & 51 & 48 & & 0.05 & $0.35 \mathrm{Ti}$ \\
$\begin{array}{c}\text { Inconel filler } \\
\text { metal 625 }\end{array}$ & 65 & 45 & & 0.03 & \\
\hline
\end{tabular}


Two metal couplings were exposed to boiling $8 \mathrm{MHNO}_{3}$ solutions to determine their corrosion behavior. These couplings were made by Gamah and involved a metal seal using a metal gasket. The couplings were made from Sch 40 2-in. T-304L stainless steel pipe (2.067-in. ID). In one case the gasket was T-304 stainless steel, and in the other it was a titanium alloy containing $6 \% \mathrm{Al}$ and $4 \% \mathrm{~V}$. Each connector had a T-304L stainless steel pipe of the same diameter and about a 6-in.-long weld to each end. A pipe cap was attached to one of the ends. A reflux condenser was attached to the open end, and electrical heating tape was wrapped around the other end. Nitric acid was added to the assembly to completely cover the joint, and the acid was refluxed. The acid was changed weekly. At the end of the test, the joints were disassembled and examined both visually and metallographically.

\section{RESULTS}

\subsection{Corrosion of Titanium in Nitric Acid}

The influence of specimen surface-area-to-solution-volume ratio and frequency of solution change on the corrosion rate of titanium was evaluated in boiling $30 \% \mathrm{HNO}_{3}$. In each case, a $100-\mathrm{mL}$ volume was used and the surface areas were 0.5 and $10 \mathrm{~cm}^{2}$. The solution was either the same acid used for the entire 100 -h test or changed at 25 -h intervals. Four specimens were tested under each condition. Table 2 shows that average corrosion rates were greater for the smaller surface area and greater when the solution was changed every $25 \mathrm{~h}$; each incremental rate is the average from four specimens.

Table 2. Corrosion rates for titanium specimens in boiling $70 \% \mathrm{HNO}_{3}$

\begin{tabular}{ccrrrrr}
\hline $\begin{array}{c}\text { Surface } \\
\text { area } \\
\left(\mathrm{cm}^{2}\right)\end{array}$ & $\begin{array}{c}\text { Frequency } \\
\text { of solution } \\
\text { change }\end{array}$ & \multicolumn{4}{c}{$\begin{array}{c}\text { Incremental corrosion rate } \\
(\mu \mathrm{m} / \text { year })\end{array}$} & $\begin{array}{c}\text { Average } \\
\text { corrosion rate } \\
(\mu \mathrm{m} / \text { year })\end{array}$ \\
\hline 0.5 & $25 \mathrm{~h}$ & $50 \mathrm{~h}$ & $75 \mathrm{~h}$ & $100 \mathrm{~h}$ & \\
0.5 & $a$ & 140 & 155 & 265 & 380 & 235 \\
10 & $25 \mathrm{~h}$ & 66 & 135 & 180 & 195 & 145 \\
10 & $a$ & 110 & 48 & 43 & 52 & 63 \\
\hline
\end{tabular}

${ }^{a}$ Solution not changed during the $100-\mathrm{h}$ test.

The effect of surface treatment on corrosion of titanium was evaluated in $100 \mathrm{~mL}$ of boiling $70 \% \mathrm{HNO}_{3}$. The surface area of the specimens was $0.5 \mathrm{~cm}^{2}$, and the solution was changed every $25 \mathrm{~h}$. The three surface conditions were abraded, anodized, and pre-exposed for $25 \mathrm{~h}$ in $100 \mathrm{~mL}$ of boiling $70 \% \mathrm{HNO}_{3}$ containing a surface area of $125 \mathrm{~cm}^{2}$ of titanium. Although there is considerable scatter in the data, Table 3 shows that pre-exposure to a solution containing a large surface area of titanium had no beneficial effect and even may have increased the attack rate somewhat. The incremental rates are the average of duplicate specimens. On the other hand, anodization imparted some resistance to attack. The surface 
Table 3. Corrosion rates of pretreated titanium specimens in $100 \mathrm{~mL}$ of boiling $70 \% \mathrm{HNO}_{3}$

\begin{tabular}{lrrrrc}
\hline Surface treatment & \multicolumn{3}{c}{$\begin{array}{c}\text { Incremental corrosion rate } \\
(\mu \mathrm{m} / \text { year })\end{array}$} & $\begin{array}{c}\text { Average } \\
\text { corrosion rate } \\
(\mu \mathrm{m} / \mathrm{year})\end{array}$ \\
\cline { 2 - 5 } & $25 \mathrm{~h}$ & $50 \mathrm{~h}$ & $75 \mathrm{~h}$ & $100 \mathrm{~h}$ & \\
\hline Abraded & 24 & 810 & 540 & 490 & 470 \\
Pre-exposed & 340 & 330 & 860 & 900 & 610 \\
Anodized (10 min $)$ & 23 & 360 & 327 & 120 & 210 \\
\hline
\end{tabular}

appearances also were indicative of this behavior. The abraded and pre-exposed specimens were covered with black tarnish films following exposure, whereas the anodized specimens maintained their gray surface appearance.

The influence of anodizing time and longer exposure times on corrosion of titanium was studied in boiling $70 \% \mathrm{HNO}_{3}$. Results are given in Tables 4 and 5 . As in Table 3 , the surface area was $0.5 \mathrm{~cm}^{2}$, the acid was changed at 25 -h intervals, and the incremental rates are the average of duplicate specimens. Table 4 shows that the longer anodization (30 $\mathrm{min}$ ) decreased the average corrosion rate for the total exposure, but rates for the final two exposure periods were comparable to those for the specimens having the shorter anodization. Table 5 shows that the 10-min anodization was effective in lowering the corrosion rate for only the first $50 \mathrm{~h}$.

The inhibitive effect of iodic acid on the corrosion of titanium in boiling $70 \% \mathrm{HNO}_{3}$ is illustrated by the results listed in Table 6. The $\mathrm{HNO}_{3}$ was changed at 25 - $\mathrm{h}$ intervals, and the surface area exposed to corrosion was $0.5 \mathrm{~cm}^{2}$. Although different results during the first $50 \mathrm{~h}$ were obtained in the two experiments with iodic acid, the lower corrosion rates in its presence are evident. Furthermore, the specimens exposed in the nitric acid containing iodic acid maintained their metallic luster; the others developed gray-black surface films.

The effect of temperature on the corrosion of titanium was studied in $70 \% \mathrm{HNO}_{3}$ using a small surface area $\left(0.5 \mathrm{~cm}^{2}\right)$ and changing the acid every $25 \mathrm{~h}$. Results given in Table 7 show that the rate of attack decreased dramatically with decreasing temperature.

Table 4. Corrosion rates of pretreated titanium specimens in $100 \mathrm{~mL}$ of boiling $70 \% \mathrm{HNO}_{3}$

\begin{tabular}{lrrrrr}
\hline Surface treatment & \multicolumn{4}{c}{$\begin{array}{c}\text { Incremental corrosion rate } \\
(\mu \mathrm{m} / \text { year })\end{array}$} & $\begin{array}{c}\text { Average } \\
\text { corrosion rate } \\
\end{array}$ \\
\cline { 2 - 5 } & $25 \mathrm{~h}$ & $50 \mathrm{~h}$ & $75 \mathrm{~h}$ & $100 \mathrm{~h}$ & $(\mu \mathrm{m} /$ year $)$ \\
\hline Abraded & 24 & 810 & 540 & 490 & 470 \\
Anodized (10 min) & 23 & 360 & 325 & 120 & 210 \\
Anodized (30 min) & 70 & 15 & 150 & 405 & 160 \\
\hline
\end{tabular}


Table 5. Average corrosion rates of duplicate specimens of abraded and anodized titanium exposed to $100 \mathrm{~mL}$ of boiling $70 \% \mathrm{HNO}_{3}$

\begin{tabular}{ccc}
\hline $\begin{array}{c}\text { Exposure } \\
\text { time } \\
(\mathrm{h})\end{array}$ & \multicolumn{2}{c}{$\begin{array}{c}\text { Incremental corrosion rates } \\
(\mu \mathrm{m} / \text { year })\end{array}$} \\
\cline { 2 - 3 } & Abraded & Anodized 10 min \\
\hline 25 & 295 & 110 \\
50 & 270 & 170 \\
75 & 445 & 435 \\
100 & 270 & 270 \\
125 & 350 & 335 \\
150 & 485 & 390 \\
175 & 435 & 545 \\
200 & 520 & 700 \\
225 & 400 & 375 \\
\hline
\end{tabular}

Table 6. Average corrosion rate of duplicate specimens of titanium in $100 \mathrm{~mL}$ of boiling $70 \% \mathrm{HNO}_{3}$

\begin{tabular}{lrrrrr}
\hline \multirow{4}{*}{ Addition } & \multicolumn{4}{c}{$\begin{array}{c}\text { Incremental corrosion rate } \\
(\mu \mathrm{m} / \text { year })\end{array}$} & $\begin{array}{c}\text { Average } \\
\text { corrosion rate } \\
(\mu \mathrm{m} / \text { year })\end{array}$ \\
\cline { 2 - 5 } & $25 \mathrm{~h}$ & $50 \mathrm{~h}$ & $75 \mathrm{~h}$ & $100 \mathrm{~h}$ & \\
\hline None & 24 & 810 & 540 & 490 & 470 \\
$5 \mathrm{~g} / \mathrm{L} \mathrm{HIO}_{3}$ & $<2.5$ & $<2.5$ & $<2.5$ & $<2.5$ & $<2.5$ \\
$5 \mathrm{~g} / \mathrm{L} \mathrm{HIO}_{3}$ & 430 & 120 & $<2.5$ & $<2.5$ & 140 \\
\hline
\end{tabular}

Table 7. Average corrosion rates of titanium specimens in $100 \mathrm{~mL}$ of $70 \% \mathrm{HNO}_{3}$

\begin{tabular}{crrrrr}
\hline \multirow{2}{*}{$\begin{array}{c}\text { Temperature } \\
\left({ }^{\circ} \mathrm{C}\right)\end{array}$} & \multicolumn{4}{c}{$\begin{array}{c}\text { Incremental corrosion rate } \\
(\mu \mathrm{m} / \text { year })\end{array}$} & $\begin{array}{c}\text { Average } \\
\text { corrosion rate } \\
(\mu \mathrm{m} / \text { year })\end{array}$ \\
\cline { 2 - 5 } & $25 \mathrm{~h}$ & $50 \mathrm{~h}$ & $70 \mathrm{~h}$ & $100 \mathrm{~h}$ & \\
\hline 120 & 24 & 810 & 540 & 490 & 470 \\
(boiling) & & & & & \\
80 & 78 & 39 & 16 & 55 & 47 \\
60 & 85 & $<2.5$ & $<2.5$ & $<2.5$ & 21 \\
40 & $<2.5$ & $<2.5$ & $<2.5$ & $<2.5$ & $<2.5$ \\
\hline
\end{tabular}


Crevice corrosion tests were carried out on titanium and tantalum in boiling $70 \% \mathrm{HNO}_{3}$. There was no evidence of crevice attack on either material, although dark tarnish films formed on the titanium specimens. Corrosion rates calculated from weight losses were 2.6 and $<2.5 \mu \mathrm{m} /$ year for titanium and tantalum respectively.

Weight-loss tests were performed on duplicate specimens of titanium and tantalum in boiling $70 \% \mathrm{HNO}_{3}$ containing 200,500, and $1000 \mathrm{ppm}$ of fluoride (added as sodium fluoride). Results given in Table 8 show that the corrosion rate of tantalum was detectable at the two higher fluoride concentrations but was still acceptable; whereas titanium exhibited weight gains at the higher fluoride concentrations. The weight gains were the result of the formation of a mottled white corrosion product film on the specimen surfaces. In contrast, the tantalum specimens were covered with thin interference colored films.

Table 8. Average corrosion rates of duplicate specimens

of titanium and tantalum in boiling $70 \% \mathrm{HNO}_{3}$ containing sodium fluoride

\begin{tabular}{|c|c|c|c|}
\hline \multirow{2}{*}{ Material } & \multicolumn{3}{|c|}{$\begin{array}{l}\text { Corrosion rate } \\
(\mu \mathrm{m} / \text { year })\end{array}$} \\
\hline & $\begin{array}{c}F^{-} \\
(200 \mathrm{ppm})\end{array}$ & $\begin{array}{c}\mathrm{F}^{-} \\
(500 \mathrm{ppm})\end{array}$ & $\begin{array}{c}\mathrm{F}^{-} \\
(1000 \mathrm{ppm})\end{array}$ \\
\hline Tantalum & $<2.5$ & 29 & 7.7 \\
\hline Titanium & 87 & $a$ & $a$ \\
\hline
\end{tabular}

The PR and the electrochemical potential of titanium were measured in $70 \% \mathrm{HNO}_{3}$ as a function of temperature. Results given in Fig. 1 show that the PR decreased with increasing temperature up to $\sim 100^{\circ} \mathrm{C}$, indicating an increase in corrosion rate, assuming that the current measured was the result of corrosion and not of other electrochemical reactions in the solution. The free corrosion potential increased with increasing temperature up to $\sim 80^{\circ} \mathrm{C}$ and decreased slightly thereafter. The potential of the specimen dropped to $\sim 0.8 \mathrm{~V}$ vs SCE after longer exposures at boiling. It was also observed that the potential of an abraded sample rapidly equilibrated to $0.8 \mathrm{~V}$ vs SCE when immersed in boiling $70 \% \mathrm{HNO}_{3}$.

The PR and the electrochemical potential of titanium and platinum were measured in $70 \% \mathrm{HNO}_{3}$ before and after addition of either $10 \mathrm{~g}$ of titanium powder or $5 \mathrm{~g}$ of $\mathrm{HIO}_{3}$ to $800 \mathrm{~mL}$ of acid. Results for titanium, given in Figs. 2 and 3, show that both additions rapidly increased the potential and the PR of the titanium, with titanium powder being somewhat more effective. However, with platinum, the electrochemical potential increased from 1.17 to $1.25 \mathrm{~V}$ vs SCE within $200 \mathrm{~min}$ of the titanium addition, whereas the iodic acid addition had no measurable effect on the potential. The PR of the platinum electrode was very low $\left(\sim 7 \Omega \mathrm{cm}^{2}\right)$ before the additions were made. It was not affected by iodic acid additions but decreased to $5.1 \Omega \mathrm{cm}^{2}$ within $10 \mathrm{~min}$ when titanium powder was added to the solution. The high corrosion potential and low PR values for platinum probably 
,

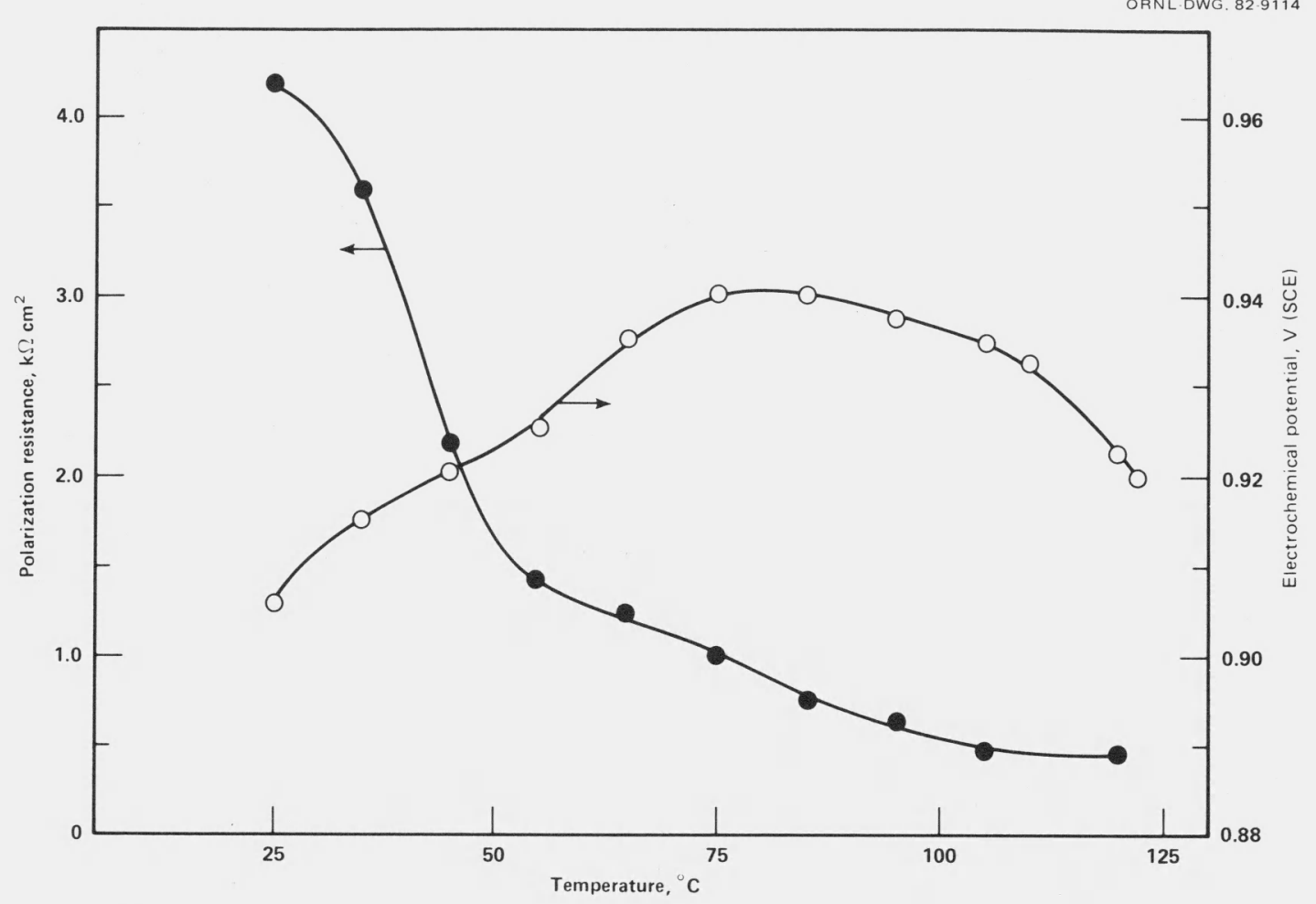

Fig. 1. Polarization resistance and potential as a function of temperature for small titanium specimens $\left(20 \mathrm{~mm}^{2}\right.$ total surface area) exposed to $800 \mathrm{~mL}$ of $70 \% \mathrm{HNO}_{3}$.

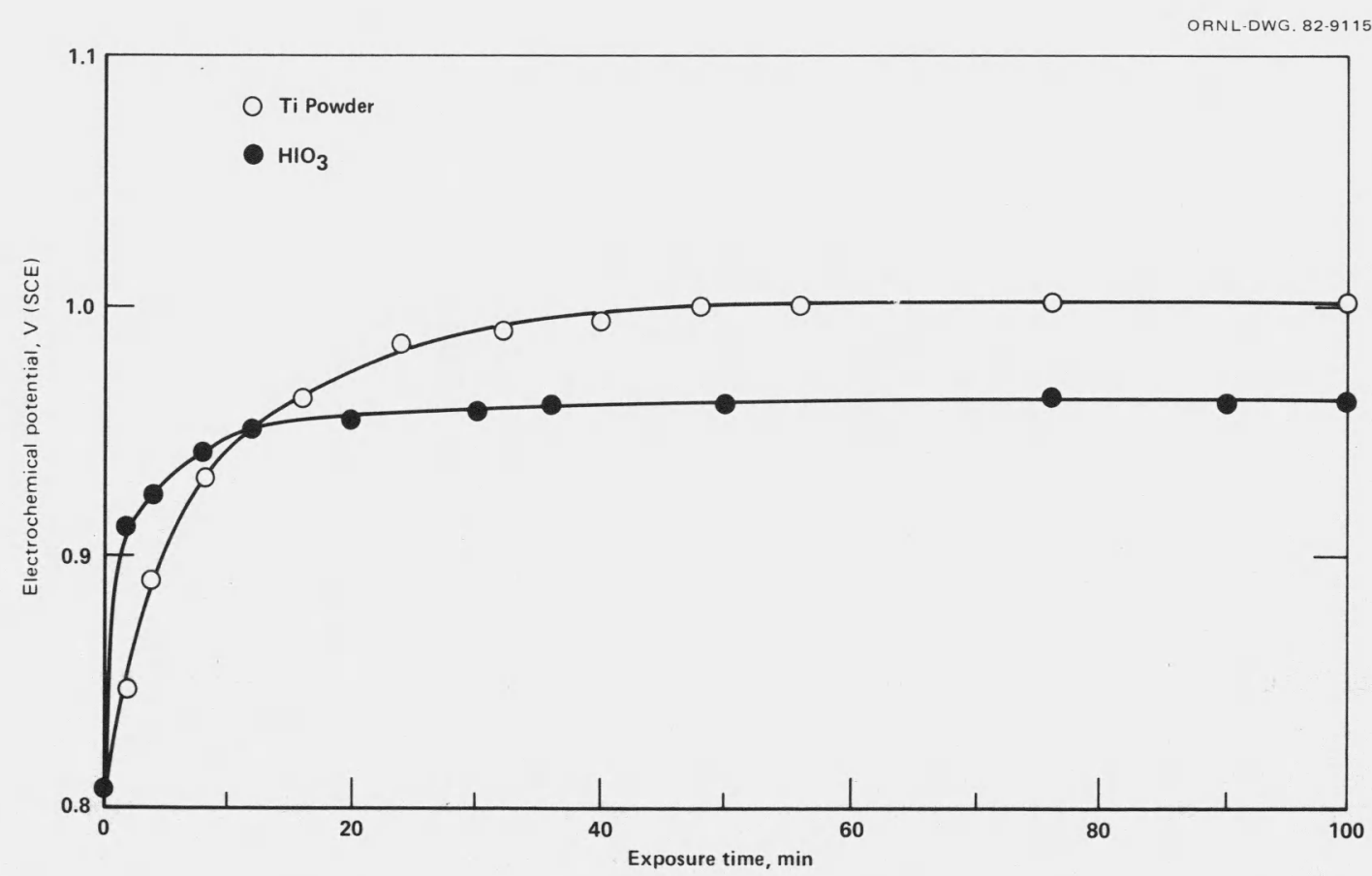

Fig. 2. Potential as a function of exposure time for titanium in boiling $70 \% \mathrm{HNO}_{3}$ following addition of either $10 \mathrm{~g}$ of titanium powder or $5 \mathrm{~g}$ of $\mathrm{HIO}_{3}$ to $800 \mathrm{~mL}$ of acid. 


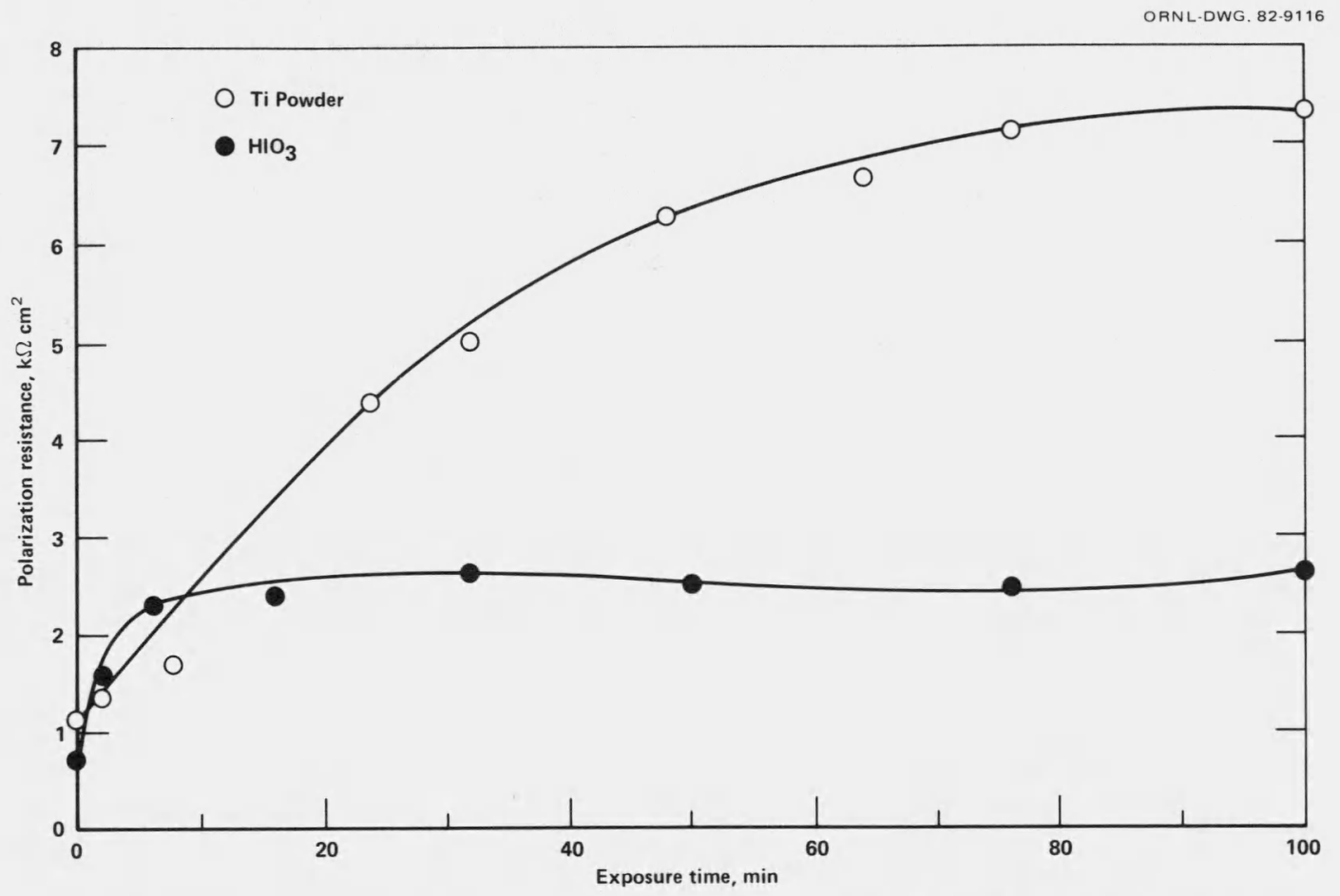

Fig. 3. Polarization resistance as a function of exposure time for titanium in boiling $\mathbf{7 0} \% \mathrm{HNO}_{3}$ following addition of either $10 \mathrm{~g}$ of titanium powder or $5 \mathrm{~g}$ of $\mathrm{HIO}_{3}$ to $800 \mathrm{~mL}$ of acid.

correspond to the reversible potential and exchange current on platinum for the dominate reaction (nitric acid reduction) in the solution. However, at these noble potentials, corrosion of platinum is possible. ${ }^{3}$

Results of the potentiodynamic and potentiostatic polarization tests on commercial grade titanium in boiling $70 \% \mathrm{HNO}_{3}$ are given in Fig. 4. These data show that titanium did not exhibit active-passive behavior in either test. In the former, the apparent corrosion current was constant above $0.95 \mathrm{~V}$ vs SCE; whereas in the latter, the current increased with increasing potential between 0.7 and $1.0 \mathrm{~V}$ vs SCE.

Figure 4 also shows that the free corrosion potential in the potentiodynamic tests was $0.86 \mathrm{~V}$ vs SCE, and stable anodic currents were measured in the potentiostatic tests at potentials more negative than this value. In the potentiodynamic tests, the scan rate was $10 \mathrm{mV} / \mathrm{min}$, and in the potentiostatic tests, the specimens were potentiostated for $50 \mathrm{~h}$. During the course of the potentiostatic tests, the currents in this potential range were initially cathodic, as one would expect from the potentiodynamic polarization behavior, but drifted to anodic values after a few hours of testing, indicating that the free corrosion potential decreased with time.

One of the most significant findings of the study was the large decrease in anodic current that occurred under potentiostatic conditions when titanium powder was added to the nitric acid. Presumably, the beneficial effect of the titanium was related to the rapid 


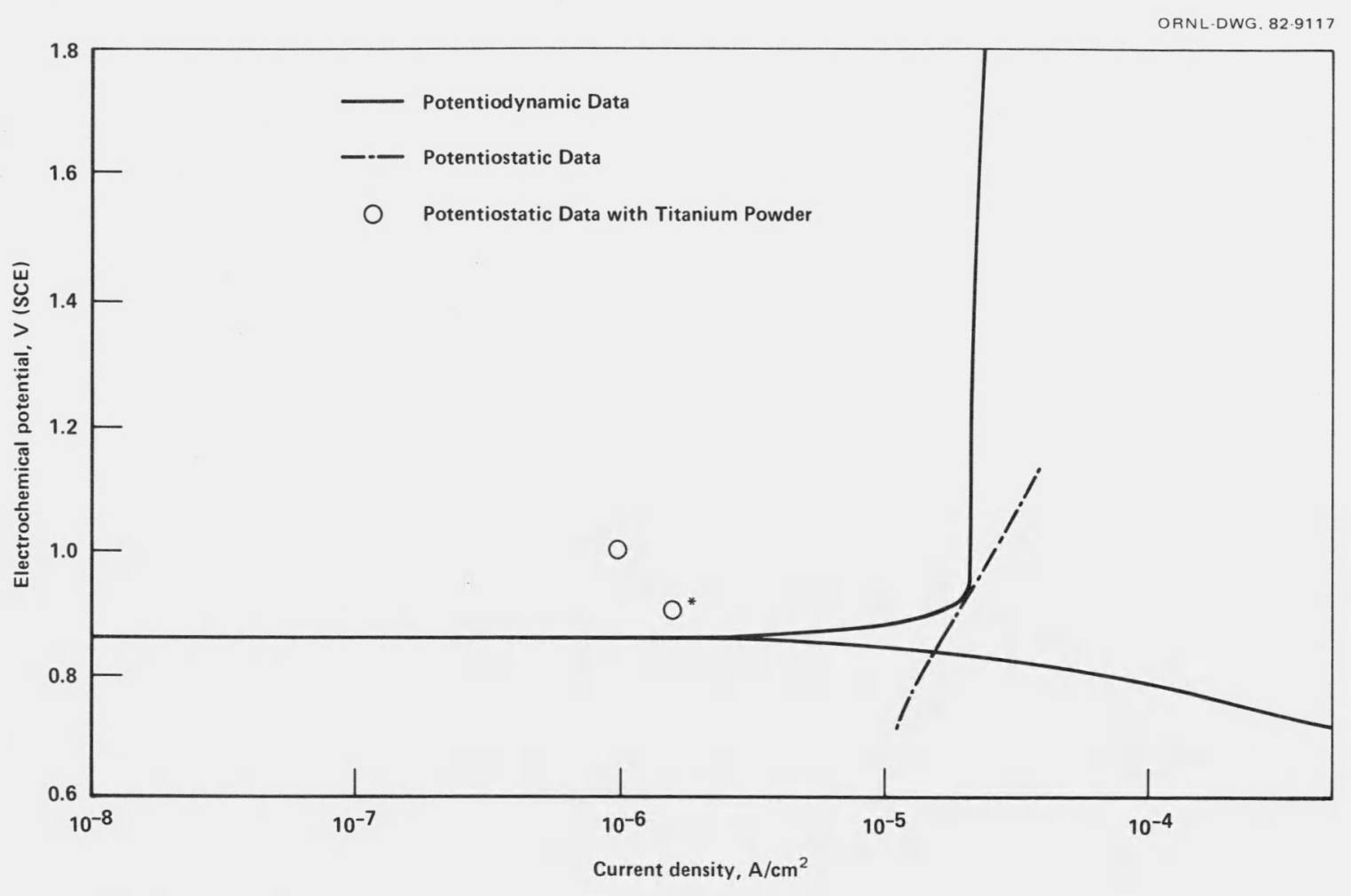

* Negative Current

Fig. 4. Results of potentiodynamic and potentiostatic polarization tests on titanium in boiling $70 \% \mathrm{HNO}_{3}$.

buildup of Ti(IV) ions in the solution (from the large surface area of titanium), which inhibited corrosion. The free corrosion potential also increased upon titanium powder addition, as indicated by the negative current measured at $+0.9 \mathrm{~V}$ vs SCE. This apparent decrease in corrosion rate (as measured electrochemically) was confirmed by weight-loss measurements performed on the potentiostated specimens (Fig. 5). Figure 5 also shows the surprisingly good agreement found between corrosion rates calculated electrochemically and those measured from weight loss.

Results of potentiostatic polarization tests performed on titanium in boiling $70 \% \mathrm{HNO}_{3}$, to which either $10 \mathrm{~g} / \mathrm{L}$ of $\mathrm{HIO}_{3}$ or $10 \mathrm{~g} / \mathrm{L}$ of titanium powder were added, or in the absence of any additions, are given in Table 9. These data show that iodic acid inhibited the corrosion of titanium under potentiostated conditions, but that the effect was not so great as that observed for the titanium powder addition. 


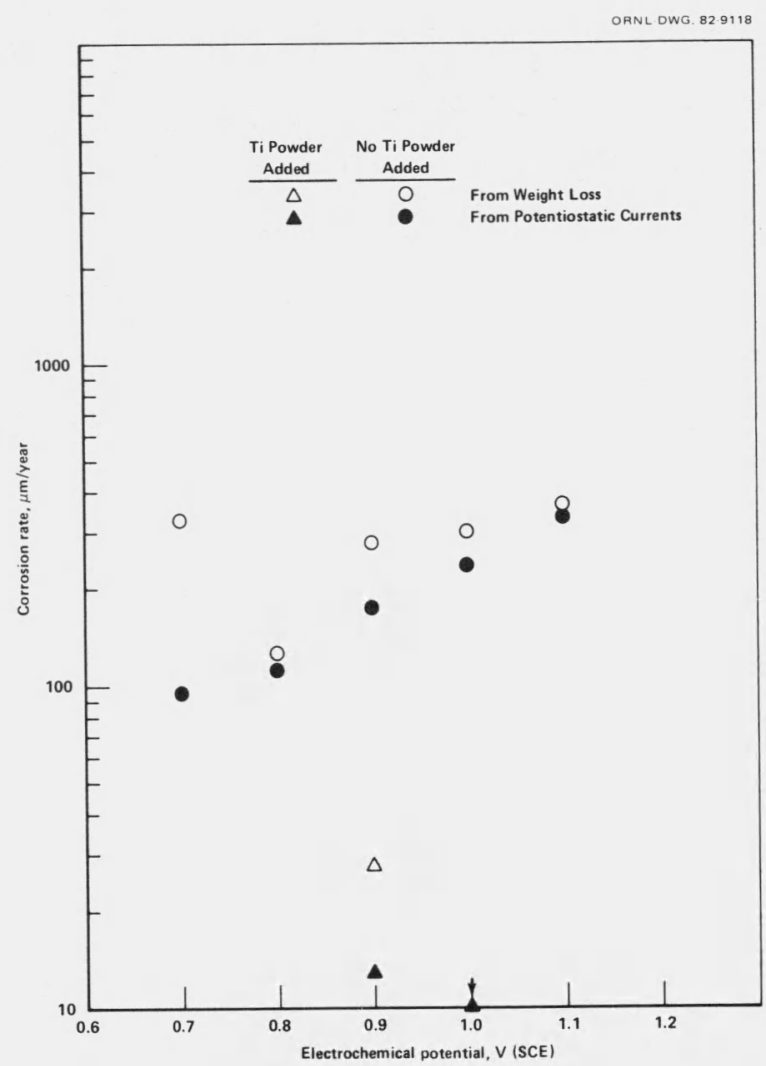

Fig. 5. Corrosion rates calculated from weight-loss and potentiostatic currents for titanium in boiling $70 \% \mathrm{HNO}_{3}$ at various potentials with and without $10 \mathrm{~g}$ of titanium powder added to $800 \mathrm{~mL}$ of the solution.

Table 9. Results of potentiostatic polarization tests of 50-h duration performed on titanium in boiling $70 \% \mathrm{HNO}_{3}$ containing various additions

\begin{tabular}{lcccc}
\hline \multirow{2}{*}{$\begin{array}{c}\text { Solution } \\
\text { addition }\end{array}$} & $\begin{array}{c}\text { Potential, } \\
\text { V(SCE) }\end{array}$ & $\begin{array}{c}\text { Current density, } \\
\mathrm{A} / \mathrm{cm}^{2}\end{array}$ & $\mu \mathrm{c}$ Corrosion rate \\
\cline { 5 - 6 } None & 0.7 & $1.1 \times 10^{-5}$ & 95 & $\mu \mathrm{m} / \mathrm{year}^{b}$ \\
None & 0.8 & $1.3 \times 10^{-5}$ & 112 & 300 \\
None & 0.9 & $2.0 \times 10^{-5}$ & 172 & 130 \\
None & 1.0 & $2.7 \times 10^{-5}$ & 185 & 280 \\
None & 1.1 & $3.8 \times 10^{-5}$ & 328 & 300 \\
$\mathrm{Ti}$ & 0.9 & $1.5 \times 10^{-6}$ & 13 & 360 \\
$\mathrm{Ti}^{\mathrm{i}}$ & 1.0 & $1.0 \times 10^{-6}$ & 8.6 & 28 \\
$\mathrm{HIO}_{3}$ & 0.8 & $5.5 \times 10^{-6}$ & 48 & 42.5 \\
$\mathrm{HIO}_{3}$ & 0.9 & $2.0 \times 10^{-6}$ & 17 & 28 \\
$\mathrm{HIO}_{3}$ & 1.0 & $1.9 \times 10^{-7}$ & 1.6 & 92 \\
\hline
\end{tabular}

${ }^{a}$ Calculated from current density at end of test. Since current density decreased during the early part of the test, these rates should generally be less than those obtained from weight loss.

${ }^{b}$ From weight loss. 


\subsection{Corrosion of Inconel 690 and 671 in Nitric Acid-Hydrofluoric Acid}

Results of gravimetric corrosion tests on unwelded and welded specimens of Inconel 690 and 671 in boiling $8 \mathrm{MHNO}_{3}-0.05 \mathrm{MHF}$ are presented in Table 10 . These data show that Inconel 671 had the greater corrosion resistance, but both alloys were less resistant to attack in the welded condition. The specimens were optically examined following exposure, and both materials showed evidence of general surface etching and some end-grain attack (Fig. 6). In addition, the heat-affected zone of the welded Inconel 690 specimen showed slight evidence of preferential attack (Figs. 7 and 8).

Table 10. Corrosion rates for welded and unwelded specimens of two nickel alloys exposed to boiling $8 \mathrm{MHNO}_{3}-0.5 \mathrm{M} \mathrm{HF}$ for four 50 -h periods

\begin{tabular}{llrrrrr}
\hline \multirow{2}{*}{ Alloy } & Condition & \multicolumn{4}{c}{$\begin{array}{c}\text { Corrosion rate } \\
(\mu \mathrm{m} / \mathrm{year})\end{array}$} \\
\cline { 3 - 6 } & & \multicolumn{4}{c}{$50 \mathrm{~h}$ periods } & \multirow{2}{*}{ Average } \\
\cline { 3 - 6 } & & \multicolumn{1}{c}{ 1st } & 2nd & 3rd & 4th & \\
\hline Inconel 690 & Unwelded & 610 & 640 & 205 & 320 & 445 \\
Inconel 690 & Welded & 1090 & 1000 & 400 & 890 & 845 \\
Inconel 671 & Unwelded & 310 & 200 & 200 & 315 & 255 \\
Inconel 671 & Welded & 580 & 390 & 420 & 535 & 480 \\
\hline
\end{tabular}

Results of gravimetric corrosion tests performed on two heat treatments of Inconel 671 in boiling $8 \mathrm{M} \mathrm{HNO}_{3}-0.05 \mathrm{M} \mathrm{HF}$ are given in Table 11 . These data show that furnace cooling decreased the corrosion resistance of the Inconel 671 over that of the air-cooled material, but the effect was not nearly so large as that reported in another study. ${ }^{4}$

The specimens of Inconel 671 were metallographically polished and examined following exposure. Figure 9 shows that the air-cooled structure consisted primarily of a single phase, with spheroidized or rod-shaped second-phase particles. The furnace-cooled structure, on the other hand, was composed of a two-phase platelet structure (in the center of the specimen) that was similar in appearance to pearlite in ferritic steels (see Figs. 10 and II). Figure 12 shows that this two-phase structure is much more susceptible to attack in boiling $\mathrm{HNO}_{3}-\mathrm{HF}$ than the single-phase material. The location of the two-phase structure in the center of the specimen may explain why a much higher corrosion rate for the furnace-cooled material was observed in a previous study. ${ }^{4}$ In that study, it is possible that the specimens were more fully converted to the two-phase structure than in the present study.

An additional weight-loss test was performed on duplicate furnace-cooled specimens of Inconel 671 that had been sectioned prior to exposure so that more of the two-phase structure could be exposed to the solution. Results given in Table 11 show that these specimens corroded at a higher rate than those not sectioned prior to exposure. 


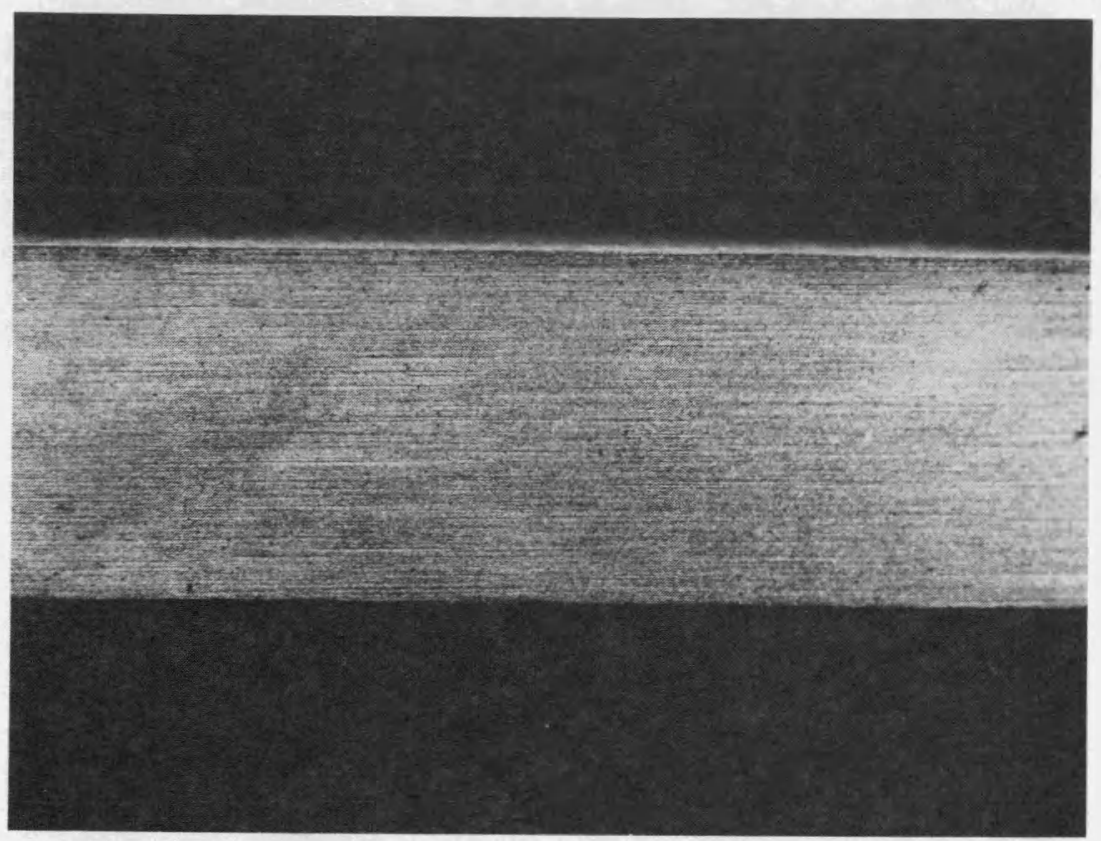

a. Inconel 671

$3 K 550$

ORNL-PHOTO. 0382-82

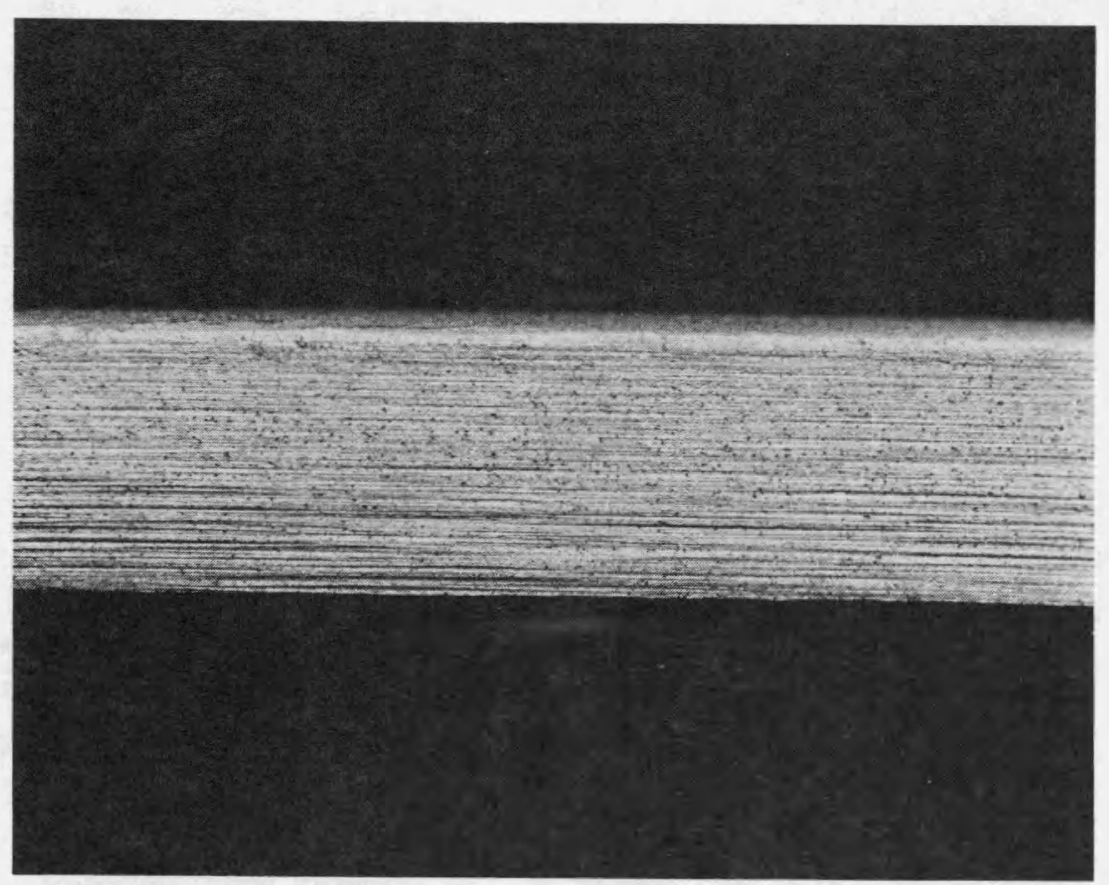

b. Inconel 690

$3 K 522$

Fig. 6. Low power optical photograph of ends of Inconel 671 and Inconel 690 specimens following exposure to boiling $8 \mathrm{MHNO}_{3}-0.05 \mathrm{M}$ HF for four 50 -h periods (specimen thickness $-3.2 \mathrm{~mm}$ ); note the evidence of grain-dropping. 
ORNL-PHOTO. 0383-82

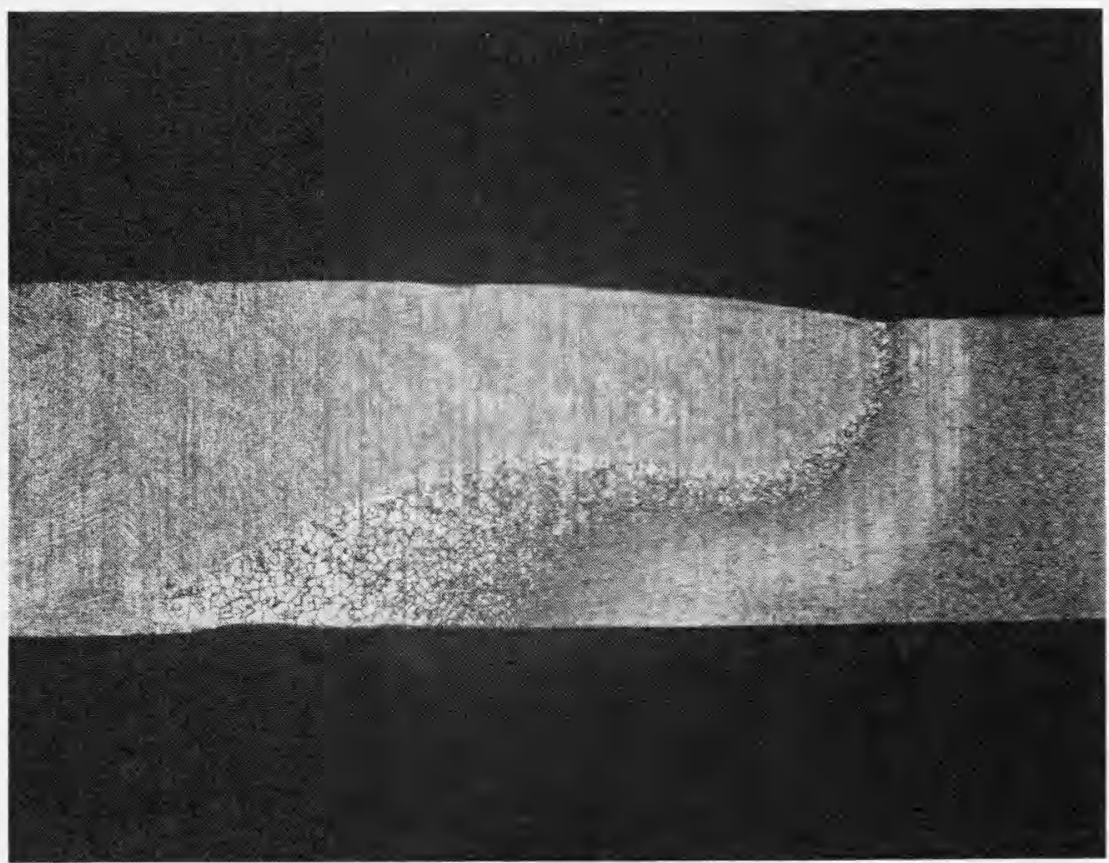

$3 K 520$

Fig. 7. Low power optical photograph of side face of welded Inconel 690 specimen following exposure to boiling $8 \mathrm{M} \mathrm{HNO}_{3}-0.05 \mathrm{M}$ HF for four 50-h periods (specimen thickness $-3.2 \mathrm{~mm}$ ); note the evidence of attack in the heat affected zone of the weld.

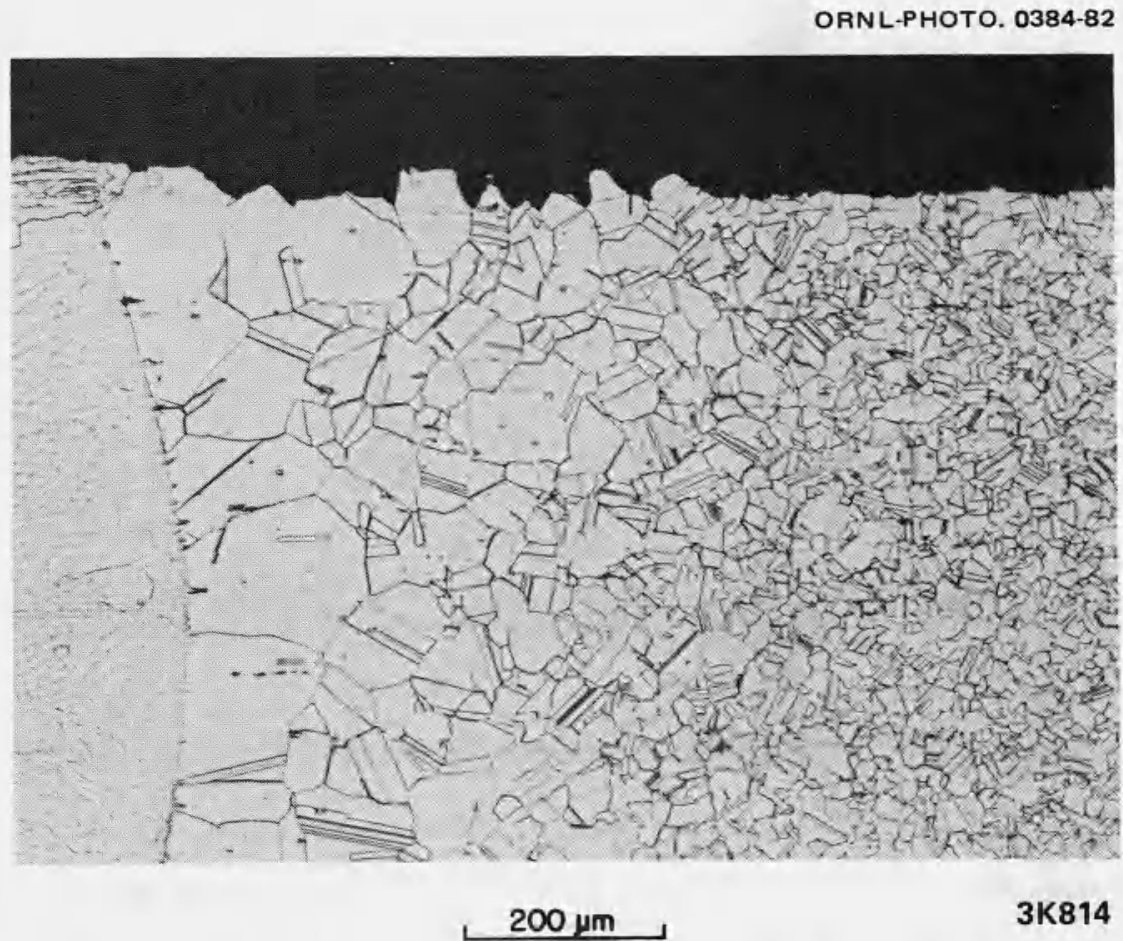

Fig. 8. Optical photograph of metallographic section of welded Inconel 690 specimen that was exposed to boiling $8 \mathrm{MHNO}_{3}-0.05 \mathrm{M} \mathrm{HF}$ for four 50 -h periods. 
Table 11. Results of weight-loss tests performed on two heat treatments of Inconel 671 in boiling $8 \mathrm{MHNO}_{3}-0.05 \mathrm{MHF}$

\begin{tabular}{lllll}
\hline \multirow{2}{*}{\multicolumn{1}{c}{ Heat treatment }} & \multicolumn{4}{c}{$\begin{array}{c}\text { Corrosion rate } \\
(\mu \mathrm{m} / \text { year })\end{array}$} \\
\cline { 2 - 5 } & $50 \mathrm{~h}$ & $100 \mathrm{~h}$ & $150 \mathrm{~h}$ & $200 \mathrm{~h}$ \\
\hline Air cooled & 330 & 270 & 330 & 250 \\
Furnace cooled & 460 & 310 & 430 & 470 \\
Furnace cooled and sectioned & 780 & 420 & & \\
\hline
\end{tabular}

${ }^{a}$ Averaged for duplicate specimens.

ORNL-PHOTO. 0385-82

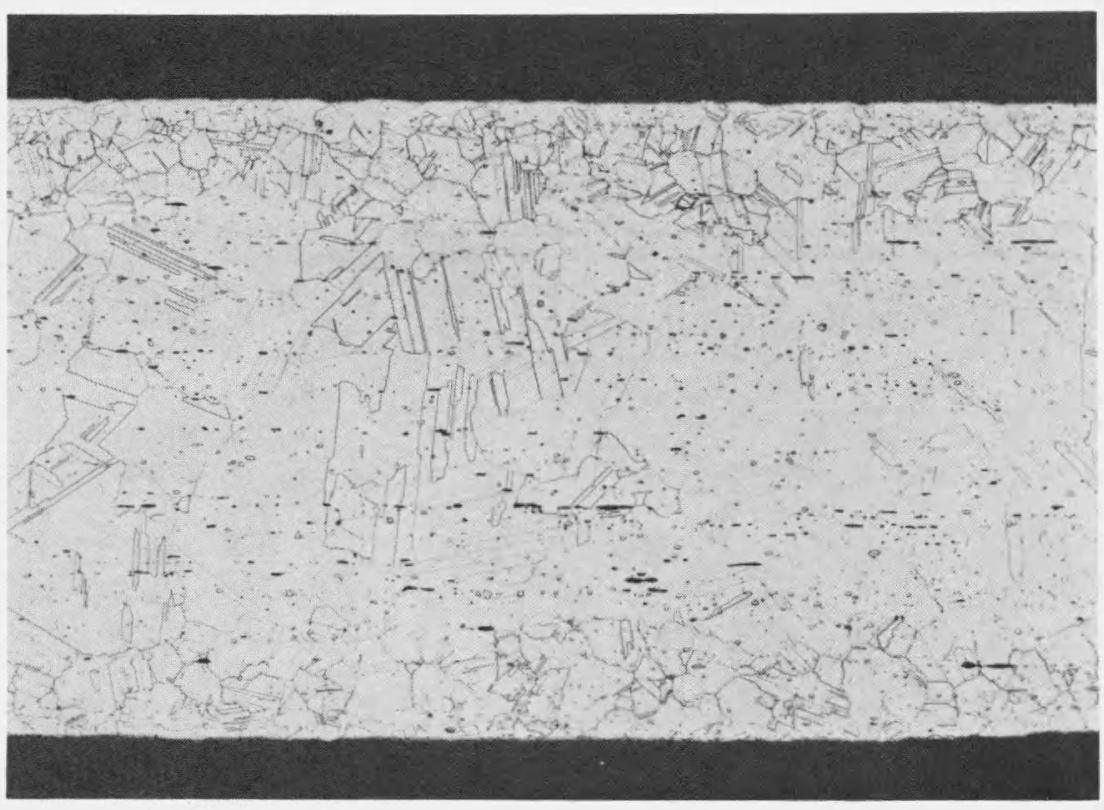

$4 K 397$

Etchant $97 \mathrm{~mL} \mathrm{HCl}, 3 \mathrm{~mL} \mathrm{HNO}_{3}, 1 / 2 \mathrm{~g} \mathrm{CuCl}_{2}$

Fig. 9. Optical photograph of metallographic section of Inconel 671 specimen that was heat treated at $1200^{\circ} \mathrm{C}$ for $2 \mathrm{~h}$, air cooled, and exposed to boiling $8 \mathrm{MHNO}_{3}-0.05 \mathrm{MHF}$ for $200 \mathrm{~h}$ (specimen thickness $-1.6 \mathrm{~mm}$ ). 


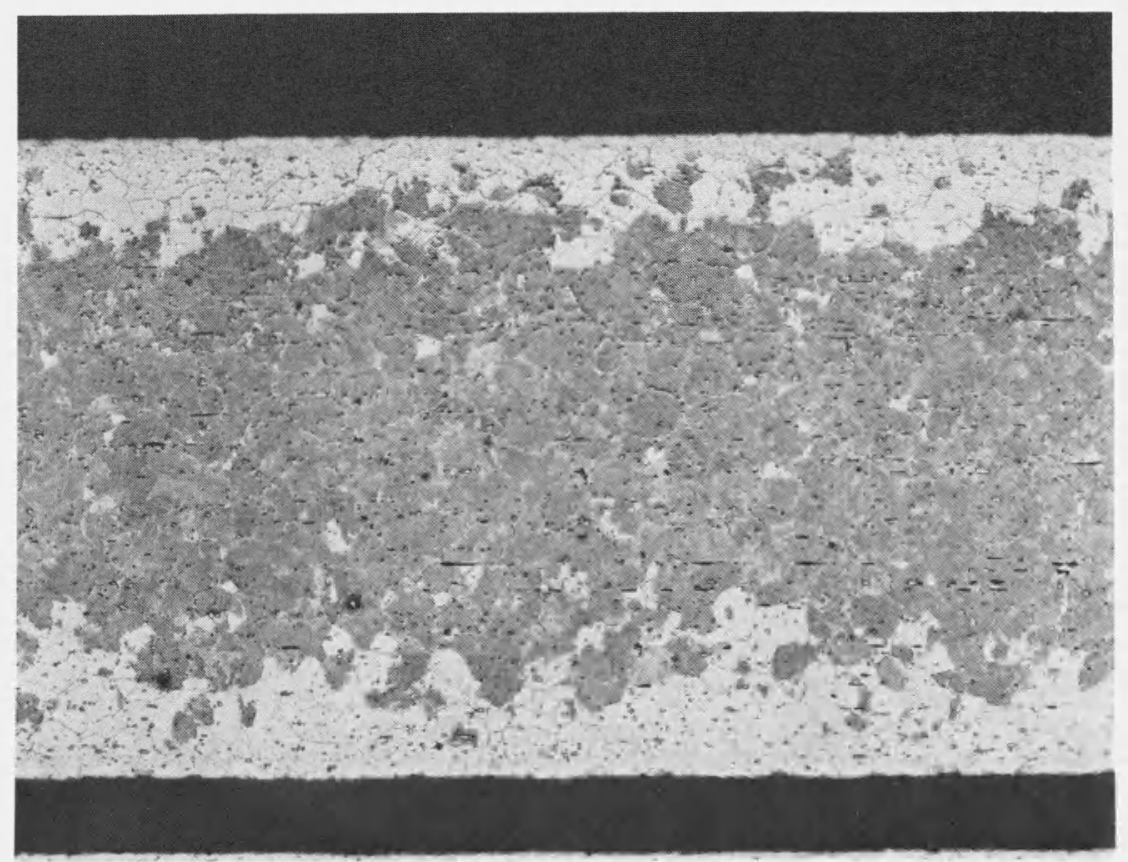

$4 K 398$

Etchant $97 \mathrm{~mL} \mathrm{HCl}, 3 \mathrm{~mL} \mathrm{HNO}_{3}, 1 / 2 \mathrm{~g} \mathrm{CuCl}_{2}$

Fig. 10. Optical photograph of metallographic section of Inconel 671 specimen that was heat treated at $1200^{\circ} \mathrm{C}$ for $2 \mathrm{~h}$, furnace cooled, and exposed to boiling $8 \mathrm{MHNO} \mathrm{HO}_{3}-0.05 \mathrm{MHF}$ for $200 \mathrm{~h}$ (specimen thickness $-1.6 \mathrm{~mm}$ ). 
ORNL-PHOTO. 0387-82

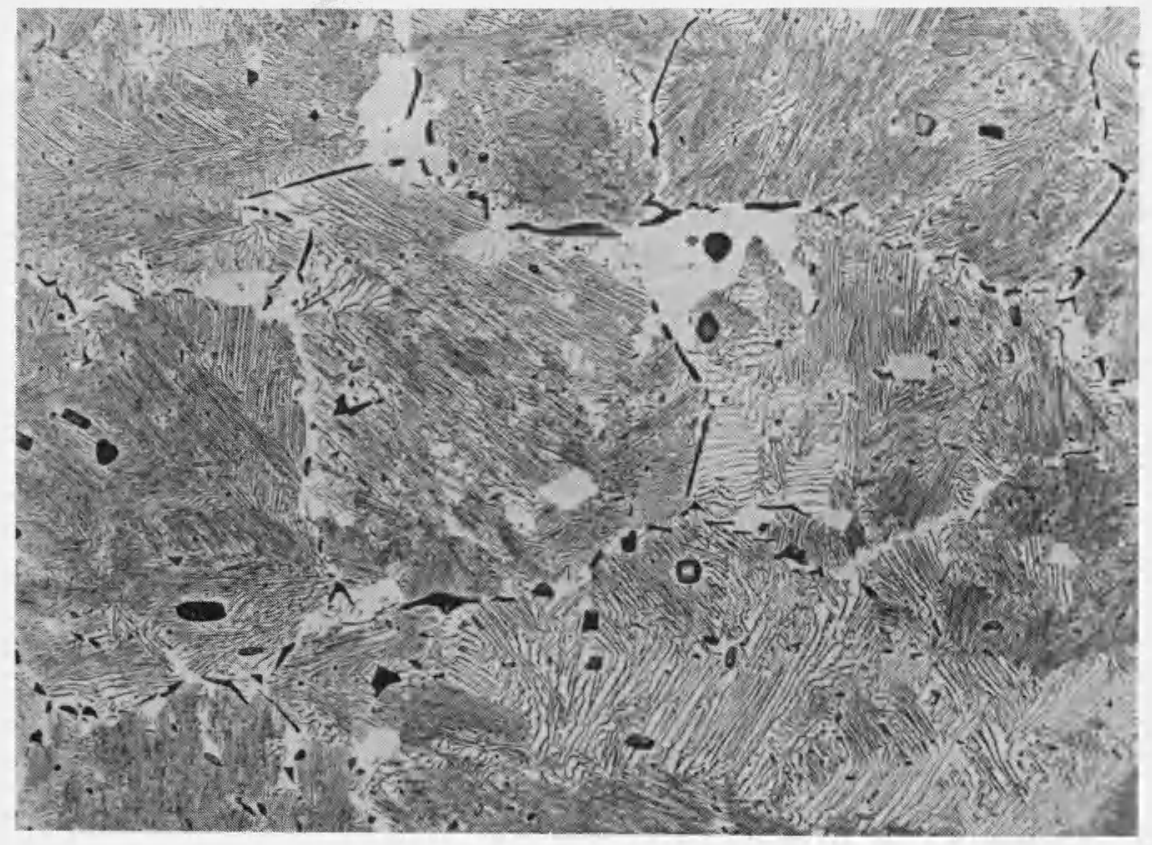

$500 x$

4K399

Etchant $97 \mathrm{~mL} \mathrm{HCl}, 3 \mathrm{~mL} \mathrm{HNO}_{3}, 1 / 2 \mathrm{~g} \mathrm{CuCl}_{2}$

Fig. 11. Center region of specimen shown in Fig. 10. 
RNL-PHOTO. 0388-82

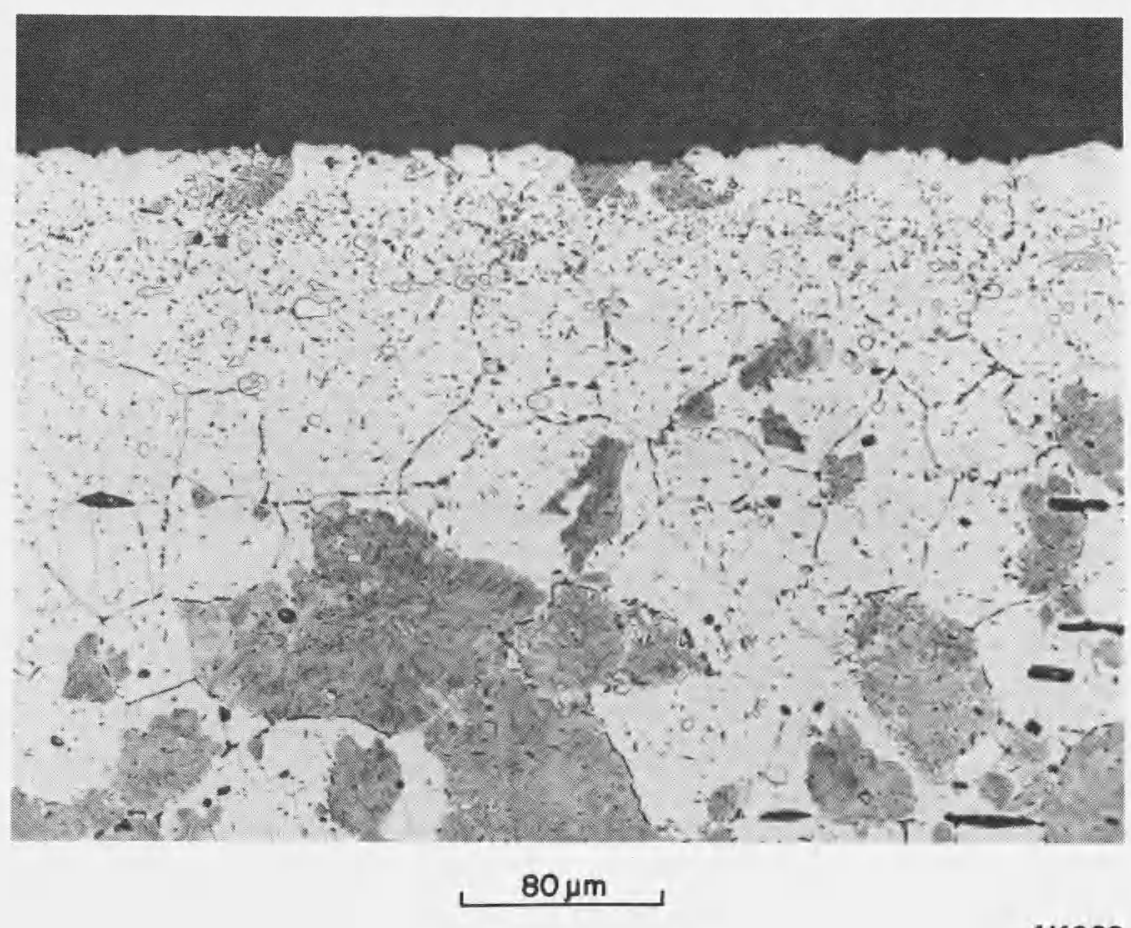

Etchant $97 \mathrm{~mL} \mathrm{HCl}, 3 \mathrm{~mL} \mathrm{HNO} 3,1 / 2 \mathrm{~g} \mathrm{CuCl}_{2}$

Fig. 12. Edge region of specimen (shown in Fig. 10) showing attack of the two-phase structure. 
A 1176-h test was performed on duplicate welded specimens of Inconel 671 in boiling $8 \mathrm{MHNO}_{3}-0.05 \mathrm{MH}$. The solutions were changed, and the specimens were weighed weekly. Results showed that the corrosion rate was nearly constant throughout the test and averaged $684 \mu \mathrm{m} /$ year.

\subsection{Hexavalent Chromium Studies}

The influence of nitric acid concentration on the formation of $\operatorname{Cr}(\mathrm{VI})$ was evaluated under boiling conditions in aqueous solutions initially containing $100 \mathrm{ppm}$ of $\mathrm{Cr}$ (III). The presence of $\mathrm{Cr}(\mathrm{VI})$ in nitric acid solutions is known to enhance the corrosion rate of stainless steel. Results given in Table 12 indicate that the formation rate of $\mathrm{Cr}(\mathrm{VI})$ increased significantly with increasing acid concentration between 5 and $9 M$.

Table 12. The effect of exposure time and $\mathrm{HNO}_{3}$ concentration on the oxidation of $\mathrm{Cr}(\mathrm{III})$ and $\mathrm{Cr}(\mathrm{VI})$ in boiling $\mathrm{HNO}_{3}$ solutions initially containing $100 \mathrm{ppm}$ of $\mathrm{Cr}(\mathrm{III})$

\begin{tabular}{|c|c|c|c|c|c|c|}
\hline \multirow{2}{*}{$\begin{array}{c}\text { Initial } \\
\mathrm{HNO}_{3} \\
(M)\end{array}$} & \multicolumn{3}{|c|}{$\begin{array}{c}\mathrm{Cr}(\mathrm{VI}) \\
(\mu \mathrm{g} / \mathrm{mL})\end{array}$} & \multicolumn{3}{|c|}{$\begin{array}{c}\mathrm{HNO}_{3} \\
(M)\end{array}$} \\
\hline & $100 \mathrm{~h}$ & $200 \mathrm{~h}$ & $300 \mathrm{~h}$ & $100 \mathrm{~h}$ & $200 \mathrm{~h}$ & $300 \mathrm{~h}$ \\
\hline 5 & 5.4 & 3.0 & 2.5 & 5.0 & 5.3 & 5.7 \\
\hline 7 & 5.6 & 13.0 & 14.0 & 7.1 & 7.1 & 7.8 \\
\hline 9 & 11.0 & 9.8 & 22.0 & 8.0 & 9.0 & 9.2 \\
\hline
\end{tabular}

The effect of ruthenium additions to $9 \mathrm{M} \mathrm{HNO}_{3}$ on formation of $\mathrm{Cr}(\mathrm{VI})$ was evaluated under boiling conditions in solutions initially containing $100 \mathrm{ppm}$ of $\mathrm{Cr}$ (III). Ruthenium was added as the chloride, the nitrate, or as a metal powder at a concentration of $100 \mathrm{ppm}$. Results given in Table 13 suggest that $\mathrm{RuCl}_{3}$ inhibited $\mathrm{Cr}(\mathrm{VI})$ formation, ruthenium powder accelerated it somewhat, and $\mathrm{Ru}\left(\mathrm{NO}_{3}\right)_{3}$ had no significant effect. It should be noted that in the last three tests shown in Table 13, the concentration of nitric acid increased substantially during the test because of loss of water from the condenser.

Table 13. The effect of exposure time and ruthenium form on the oxidation of $\mathrm{Cr}$ (III) to $\mathrm{Cr}$ (VI) in boiling $9 \mathrm{M} \mathrm{HNO}_{3}$ initially containing $100 \mathrm{ppm}$ of both $\mathrm{Cr}$ (III) and ruthenium

\begin{tabular}{lrrrrrrr}
\hline \multirow{2}{*}{$\begin{array}{l}\text { Ruthenium } \\
\text { compound }\end{array}$} & \multicolumn{3}{c}{$\begin{array}{c}\mathrm{Cr}(\mathrm{VI}) \\
(\mu \mathrm{g} / \mathrm{mL})\end{array}$} & & \multicolumn{3}{c}{$\begin{array}{c}\mathrm{HNO}_{3} \\
(M)\end{array}$} \\
\cline { 2 - 4 } \cline { 7 - 8 } & $100 \mathrm{~h}$ & $200 \mathrm{~h}$ & $300 \mathrm{~h}$ & & $100 \mathrm{~h}$ & $200 \mathrm{~h}$ & $300 \mathrm{~h}$ \\
\hline None & 11.0 & 9.8 & 22.0 & & 8.8 & 9.0 & 9.2 \\
$\mathrm{RuCl}_{3}$ & 2.8 & 3.3 & 5.8 & & 9.0 & 9.2 & 10.3 \\
$\mathrm{Ru} \mathrm{powder}$ & 6.2 & 22.0 & 47.0 & & 9.1 & 9.5 & 10.6 \\
$\mathrm{Ru}\left(\mathrm{NO}_{3}\right)_{3}$ & 8.3 & 10.0 & 39.0 & & 9.0 & 9.5 & 11.7 \\
\hline
\end{tabular}


The effect of sparging boiling $70 \% \mathrm{HNO}_{3}$ with air or $\mathrm{NO}_{2}$ from an open-ended tube on formation of $\mathrm{Cr}(\mathrm{VI})$ was evaluated in a solution containing $100 \mathrm{ppm}$ of $\mathrm{Cr}(\mathrm{III})$. Results presented in Table 14 suggest that the rate of formation of $\mathrm{Cr}(\mathrm{VI})$ was independent of the sparging gas. Since on dissolving, $\mathrm{NO}_{2}$ forms $\mathrm{HNO}_{2}$ that reduces $\mathrm{Cr}(\mathrm{VI})$, it is clear that very little, if any, $\mathrm{HNO}_{2}$ formed under the stated conditions.

Table 14. The buildup of $\mathrm{Cr}(\mathrm{VI})$ in boiling $70 \%$

$\mathrm{HNO}_{3}$ initially containing $100 \mathrm{ppm}$ of $\mathrm{Cr}(\mathrm{III})$

\begin{tabular}{|c|c|c|c|}
\hline \multirow[t]{2}{*}{ Sparge } & \multicolumn{3}{|c|}{$\begin{array}{c}\mathrm{Cr}(\mathrm{V}) \text { concentration } \\
(\mu \mathrm{g} / \mathrm{mL})\end{array}$} \\
\hline & $100 \mathrm{~h}$ & $200 \mathrm{~h}$ & $300 \mathrm{~h}$ \\
\hline None & 51 & 55 & 66 \\
\hline Air & $50^{a}$ & $72^{a}$ & $89^{a}$ \\
\hline $\mathrm{NO}_{2}$ & $84^{a}$ & $87^{a}$ & $73^{a}$ \\
\hline
\end{tabular}

${ }^{a}$ Averaged for duplicate tests.

\subsection{Corrosion of Gamah Connectors}

Corrosion on the walls of the Gamah connectors was minimal during the exposure to boiling $8 \mathrm{MHNO}_{3}$, but the connector with the T-304 stainless steel gasket developed a leak at the joint between 450 and $500 \mathrm{~h}$ after the start of the test. The other connector that had a titanium alloy $(6 \% \mathrm{Al}-4 \% \mathrm{~V})$ gasket experienced no solution loss during the 1750 -h test. A leak test performed on the latter connector showed that its helium leak rate changed very little as a result of the exposure.

The gasket in the connector that leaked had been machined from an appropriate-sized T-304 stainless steel pipe and had undergone severe localized attack. Figure 13 is a view of a flat surface (perpendicular to the drawing direction of the pipe from which it was made) showing the extent of corrosion; in localized regions, attack extended completely through the 1/8-in.-thick material. A cross-sectional view (parallel to the drawing direction) of the same gasket is shown in Fig. 14. Figure 15 is a cross section (same orientation as in Fig. 14) through an unexposed gasket of the same material as tested and shows that the steel was of a low quality; numerous stringers and other inclusions existed in the steel, which seem to be sites where attack began and progressed in to the gasket.

Figure 16 shows how attack progressed into the ends of the stainless steel connector, and Fig. 17 shows attack on the interior wall of the T-304L stainless steel pipe that had been welded onto the connector itself. Figures 16 and 17 have the same magnification, and comparison of these shows the much greater penetration into the end of the connector than into the wall.

In the case of the connector with the titanium alloy gasket, attack on the T-304L stainless steel walls was about the same as in the case with the shorter test. However, the 


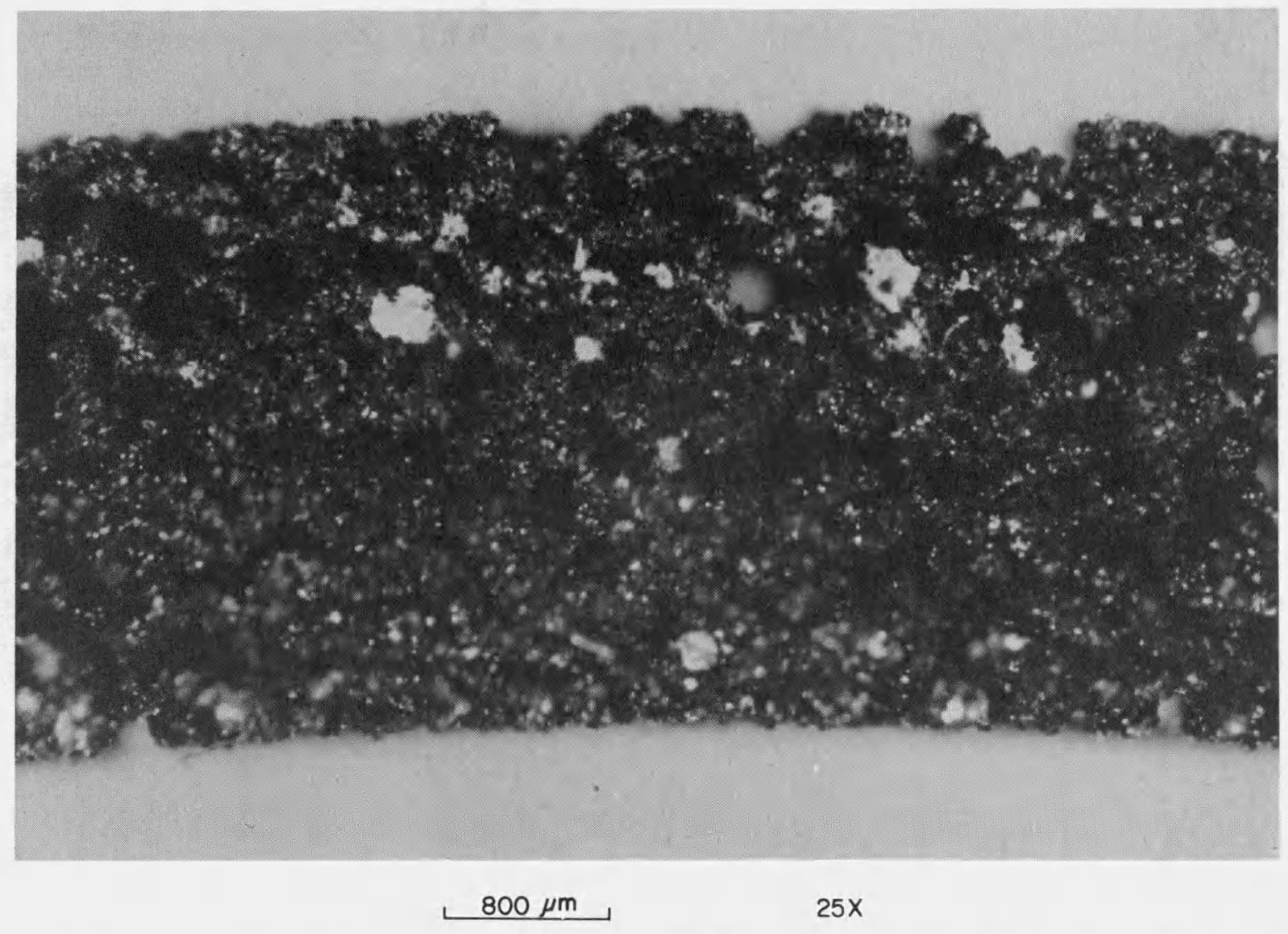
$\mathrm{HNO}_{3}$. 
ORNL-PHOTO. 0390-82

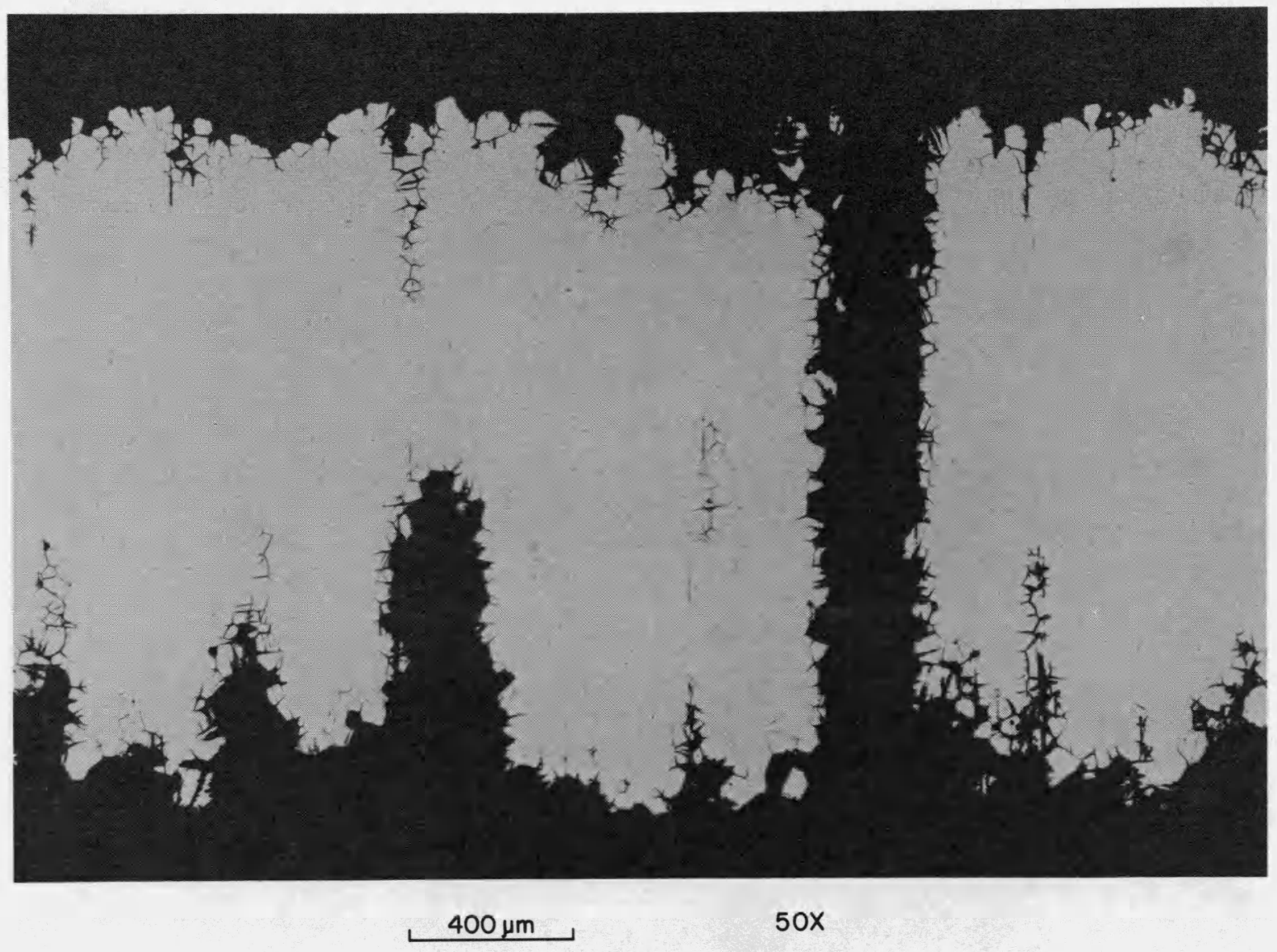

Fig. 14. Cross section through the gasket shown in Fig. 13. 
ORNL-PHOTO. 0391-82

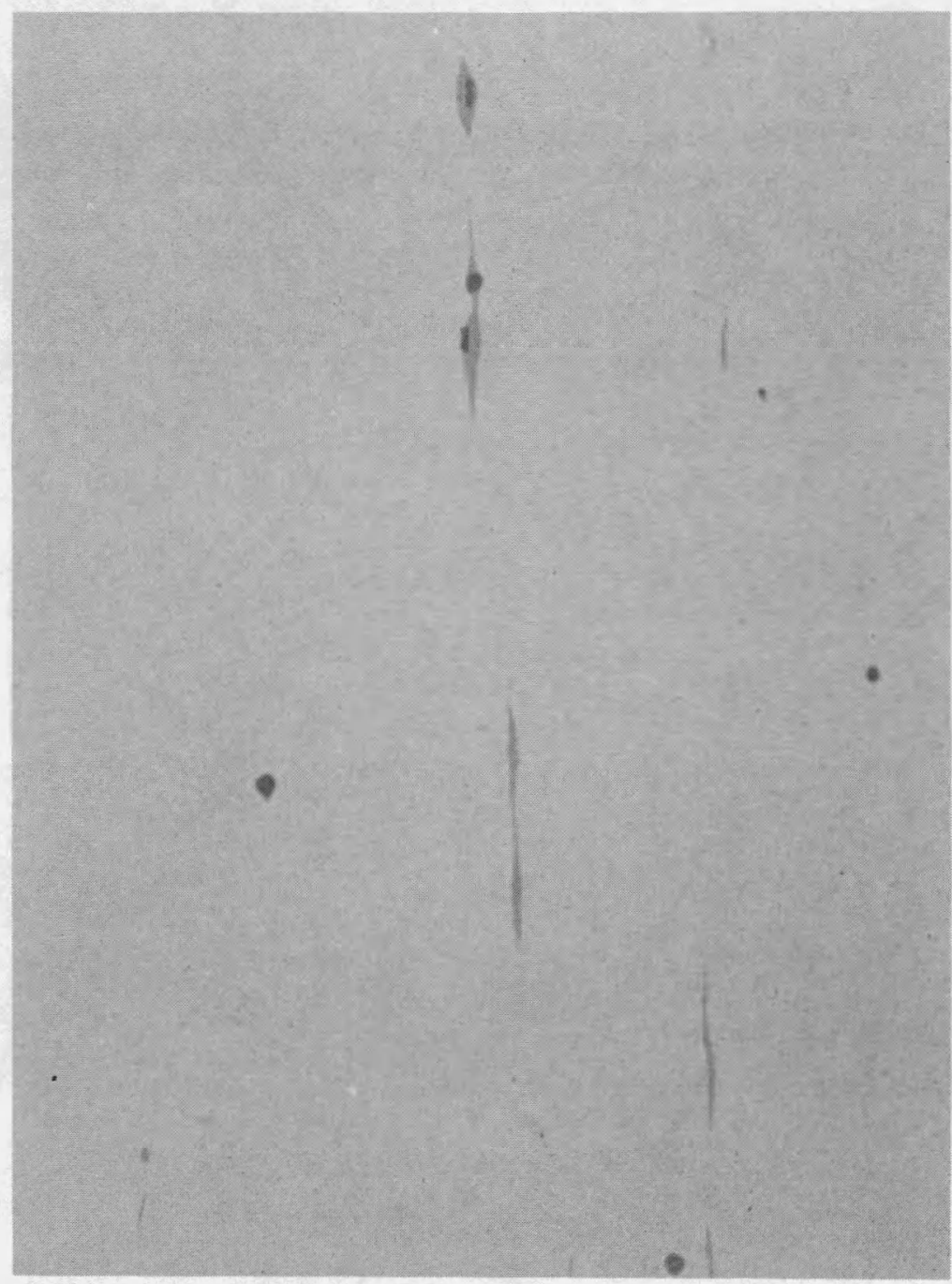

Fig. 15. Cross-sectional view through an unexposed T-304 stainless steel gasket made from the same material as that in Figs. 13 and 14. The stringers run in the thickness direction of the gasket. 
ORNL-PHOTO. $0392-82$

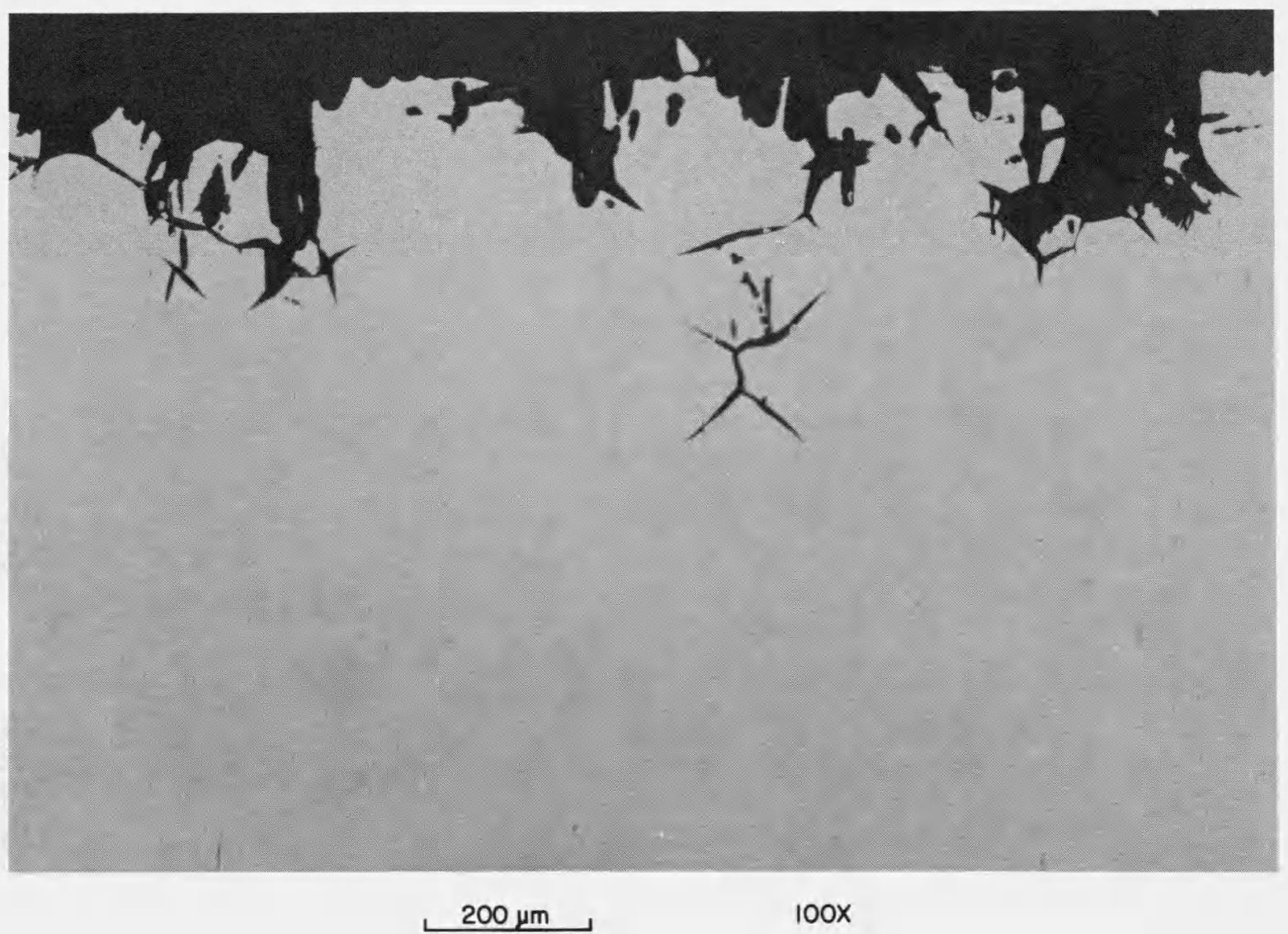

Fig. 16. End-grain attack into an end of the T-304L connector. 
ORNL-PHOTO. 0393-82

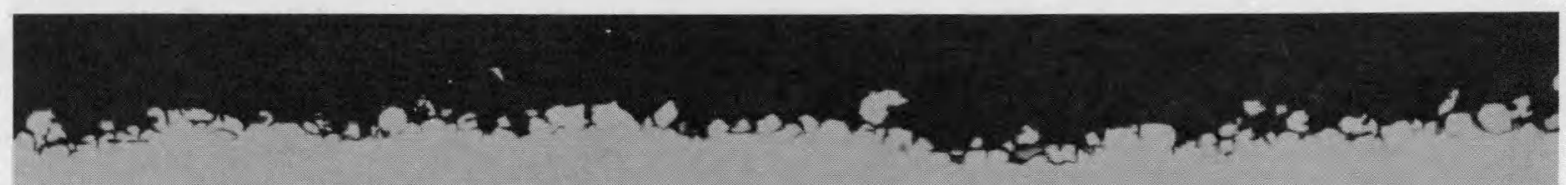

$-\cdots$

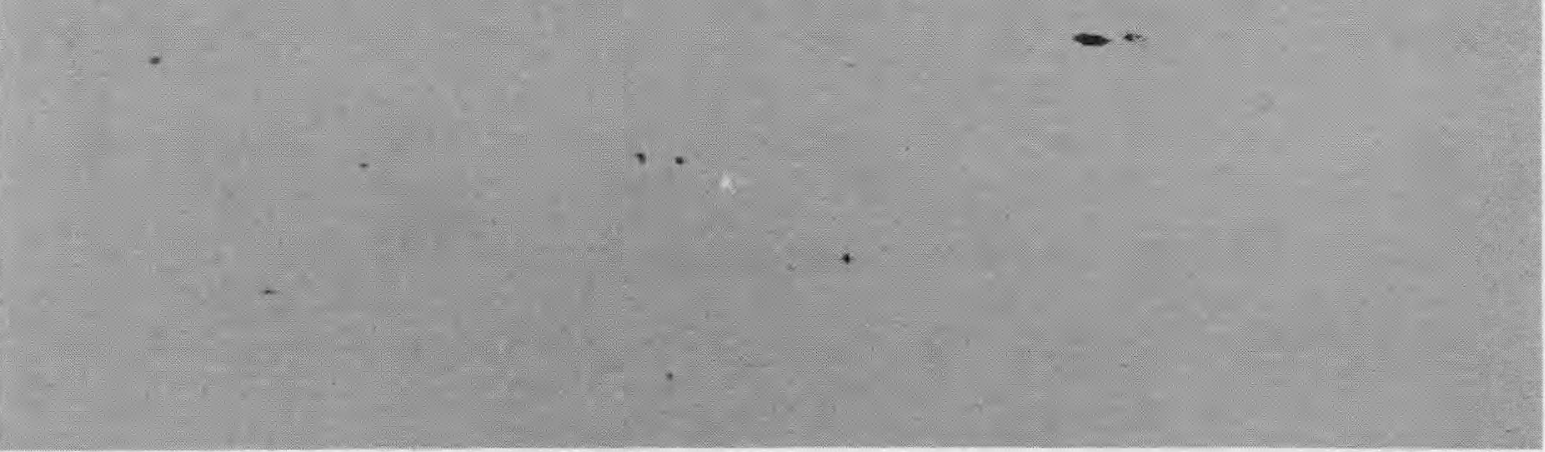

$200 \mu \mathrm{m}, 100 x$

Fig. 17. Slight intergranular attack on the T-304L stainless pipe wall. 
titanium alloy gasket seemed to have seated completely on the ends of the connector, and there was no apparent end-grain attack in this region. The gasket itself experienced attack only on those surfaces exposed directly to the acid. Figure 18 shows a flat surface of the gasket. The area showing attack was in direct contact with the solution, whereas, the unaffected area was the seating surface and showed no attack. The back side had a larger * seating surface, and the entire width showed no signs of attack. Figure 19 is a cross section through the width of the gasket and shows the type and extent of attack. X-ray diffraction patterns indicated that the surface corrosion product was primarily anatase, $\mathrm{TiO}_{2}$.

ORNL-PHOTO. 0394-82

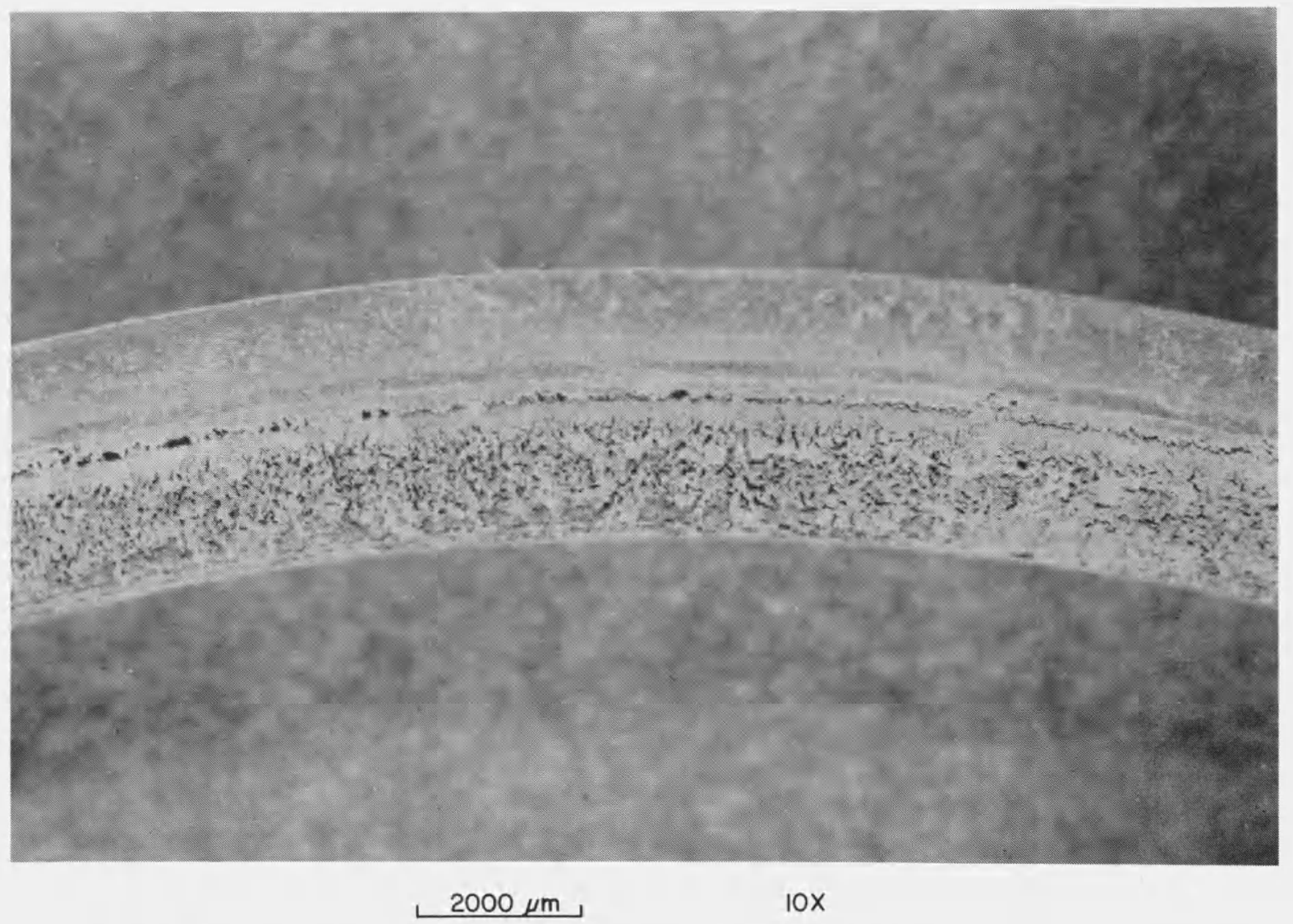

Fig. 18. Surface view of $\mathrm{Ti}-6 \% \mathrm{Al}-4 \% \mathrm{~V}$ gasket from $\mathrm{T}-304 \mathrm{~L}$ stainless steel Gamah connector exposed for $1750 \mathrm{~h}$ to boiling $8 \mathrm{MHNO}_{3}$. 
ORNL-PHOTO. 0395-82

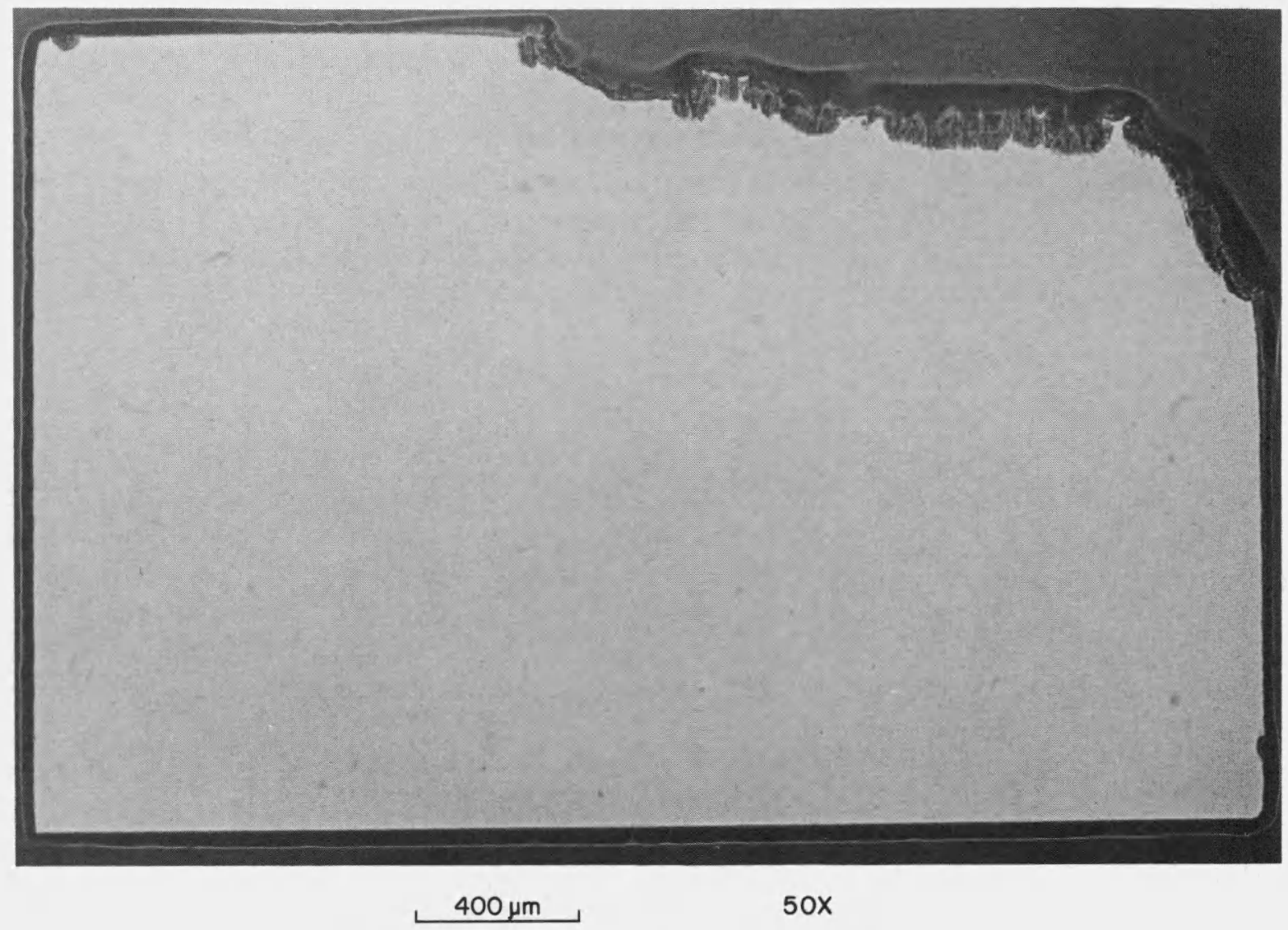

Fig. 19. Cross section through gasket shown in Fig. 18.

\section{DISCUSSION}

Although most information available in the literature indicates that titanium has very high resistance to all concentrations of nitric acid containing at least $1 \%$ water, a few investigators have noted that in hot, flowing, fresh nitric acid the corrosion of titanium can be appreciable..$^{5-7}$ Our data essentially confirm the latter results. Thus, in our tests corrosion rates were greater when the acid solution was changed frequently or when the surface area-to-solution-volume ratio was small than when the acid was unchanged or a large surface area was present in a small volume of solution. Anodization of titanium decreased the rate of attack of titanium initially but had no lasting effect. Surprisingly, the addition of iodic acid inhibited the corrosion of titanium as did adding a large surface area of titanium to the nitric acid. This last observation is consistent with Weiman's ${ }^{6}$ belief that a critical concentration of $\mathrm{Ti}(\mathrm{IV})$ in the acid is required to passivate titanium. Fortunately, the effect of the increased corrosion rate of titanium with acid refreshment diminishes rapidly with decreasing temperature. Because of this fact and the planned use of tantalum in many areas, only in a few steps of the Iodox process does corrosion of titanium appear to be a potential problem. 
Results of the electrochemical tests failed to shed much light on the mechanism of the corrosion of titanium in nitric acid. The decreased corrosion rate (in the presence of iodic acid and when the surface area-to-volume ratio was small) corresponded to an increase in corrosion potential; normally this would indicate thickening of a protective film, because all potentials involved were well in the passive potential region. One possible explanation for the effect of a large surface area of titanium may be as follows: when the potential of titanium is above the active-passive transition potential, as in nitric acid, an oxide film forms; and its rate of growth, and consequently the corrosion rate of the underlying titanium, depends on its thickness. In fresh nitric acid, the oxide has a small but finite solubility, so the oxide film remains thin, and oxidation continues at an appreciable rate. If the acid is not refreshed, the solubility limit of titanium dioxide is soon reached (more rapidly the greater the surface area of titanium), the oxide thickness on the titanium grows at a decreasing rate, and the oxidation rate of titanium soon becomes negligibly small. Although the above scenario may account for the effect of a large titanium surface area on corrosion, the reason why iodic acid inhibits attack remains obscure.

There was no reason to suspect that crevice corrosion would occur with either pure titanium or tantalum, and indeed, our results show that none occurs. It was also encouraging to find that both metals were only slightly affected by the presence of up to $200 \mathrm{ppm}$ of fluoride in boiling $70 \% \mathrm{HNO}_{3}$. The 200-ppm level is greater than would be expected as a contaminant in the Iodox process fluids as, for example, from a secondary dissolver using an $\mathrm{HNO}_{3}$ - $\mathrm{HF}$ solution.

By its very nature the secondary dissolver must be compatible with very aggressive solutions such as hydriodic acid and acid fluoride solutions. As shown in a previous study, ${ }^{8}$ there are several materials acceptable for construction of a secondary dissolver that uses hydriodic acid as solvent. However, if a nitric acid-hydrofluoric acid solution is used, choices are more limited, and Inconel 690 and 671 appear to be the most corrosion-resistant materials. Our data, as well as those of $\mathrm{Wu}^{4}$, show that fully annealed alloy 671 has better general corrosion resistance than does alloy 690 . Unless the former alloy, however, is quenched from the solution-annealed temperature, a two-phase structure containing $\alpha$ chromium and a nickel-rich phase results, and in this condition the alloy corrodes at a high rate in nitric acid. Although we did inadequate testing to make a final choice at this time between the two materials, difficulty in assuring a single-phase structure in Inconel 671 may preclude its use. Hopefully, the secondary dissolver in a plant reprocessing fast reactor fuels will see only limited service; in which case, the corrosion resistance of Inconel 690 would be adequate.

It is well established that the presence of $\mathrm{Cr}(\mathrm{VI})$ in nitric acid increases the corrosion rate of iron- and nickel-base alloys in these solutions..$^{9-11}$ Furthermore, $\mathrm{Cr}(\mathrm{VI})$ can form in nitric acid solutions in which chromium-bearing alloys are exposed. However, $\mathrm{Cr}(\mathrm{VI})$ is not stable in the presence of radiation fields ${ }^{12}$ and probably should not be of concern in any parts of a reprocessing plant. On the other hand, corrosion testing in the absence of radiation can produce overly pessimistic results, and it is probable that laboratory tests in concentrated nitric acid solutions have indicated, in some cases, higher corrosion rates than would be experienced in actual reprocessing plants. As expected, our results showed that the rate of $\mathrm{Cr}(\mathrm{VI})$ formation from $\mathrm{Cr}$ (III) increased as the acid concentration increased, and that certain forms of ruthenium could catalyze its formation. One standard method of 
preventing $\mathrm{Cr}(\mathrm{VI})$ formation is to restrict the escape of reduced oxides of nitrogen produced by corrosion or by oxidation of $\mathrm{Cr}$ (III) from the system; the oxides of nitrogen reduce $\mathrm{Cr}(\mathrm{VI})$ to $\mathrm{Cr}(\mathrm{III})$. One interesting result obtained was that simply bubbling $\mathrm{NO}_{2}$ into a boiling nitric acid solution was not effective in retarding the rate of $\mathrm{Cr}(\mathrm{VI})$ formation.

Gamah connectors give leaktight seals, are easy to assemble and disassemble, and consequently appear to be well suited for use in remotely operated reprocessing plants. In each of the two connectors tested, appreciable corrosion was experienced with the gaskets. In the first case, the T-304 stainless steel gasket had been made from a low grade tube or pipe that contained stringers and other inclusions. Because the gasket corroded, the end grains of the sealing surfaces experienced some end-grain attack, a phenomenon that is not uncommon on drawn pipes or tubing. In the second case, the gasket material was the titanium $(6 \%$ $\mathrm{Al}-4 \% \mathrm{~V}$ ) alloy, although the specification called for commercially pure titanium. The freely exposed areas of the alloy experienced attack, but corrosion did not extend into those areas between the ends of the connector, and no end-grain attack occurred. Generally pure titanium has better corrosion resistance than its alloys, and it seems likely that much less corrosion would have been encountered if it had been used.

Although, on the surface, the results obtained with the first two Gamah connectors are not encouraging, it should be noted that in each case an off-specification material produced most of the damage. Also, in both cases, the tests were conducted at the boiling point of $8 \mathrm{MHNO}_{3}$, whereas in an actual plant, most of the time that acid will contact the connector will be at cell temperature, well below our test temperature. Obviously, considerably more testing needs to be completed, but the present results should not by themselves be construed to mean that Gamah connectors will not perform satisfactorily in a remotely operated fuel element reprocessing plant.

\section{CONCLUSIONS}

As a result of the work described in this report, the following conclusions seem justified:

1. The corrosion rate of titanium depends on the rate of nitric acid replacement and is inhibited by iodic acid. The data also suggest that after the buildup of some minimal concentration of $\mathrm{Ti}(\mathrm{IV})$ in the nitric acid, the attack becomes negligibly small. The above effect is temperature dependent, becoming insignificant at temperatures below $60^{\circ} \mathrm{C}$.

2. Both titanium and tantalum are immune to crevice corrosion in nitric acid, and the presence of up to $200 \mathrm{ppm}$ of fluoride in the acid produced no significant effect on the corrosion rate of either.

3. In a secondary dissolver that uses a nitric acid-hydrofluoric acid mixture as solvent, Inconel 690 and 671 seem to have better corrosion resistance than other practical alloys, but the corrosion resistance of the latter alloy is seriously diminished unless the single-phase microstructure is preserved by rapid quenching from the annealing temperature.

4. In boiling nitric acid, the rate of oxidation of $\mathrm{Cr}$ (III) to $\mathrm{Cr}$ (VI) increases as the concentration of acid increases. In certain chemical forms, ruthenium appears to catalyze the oxidation reaction. 
5. The sealing gaskets of two Gamah connectors experienced corrosion in tests in boiling nitric acid solution; one was made from T-304 stainless steel and the other from a titanium alloy $(6 \% \mathrm{Al}, 4 \% \mathrm{~V})$. Both materials were off-specification; the stainless steel contained numerous inclusions, and pure titanium had been specified instead of the alloy. In view of these facts plus the severity of the test environment, Gamah connectors must still be considered for possible use in reprocessing plants. Further testing with specified material in realistic environments is obviously indicated.

\section{REFERENCES}

1. J. A. Beavers (Battelle Columbus Laboratories), personal communication to J. C. Griess (Oak Ridge National Laboratory), December 1979.

2. P. J. Moreland and J. C. Rowlands, "Technique and Instrumentation for Polarization Measurements," Br. Corros. J. 12(2), 72 (1977).

3. M. Pourboix, Atlas of Electrochemical Equilibria, National Association of Corrosion Engineers, Houston, Texas, 1974, p. 378.

4. P. C. S. Wu (Westinghouse Electric Corporation), personal communication to J. C. Griess (Oak Ridge National Laboratory), July 1980.

5. C. R. Bishop, "Corrosion Tests at Elevated Temperatures and Pressures," Corrosion 19, 308t-14t (1963).

6. S. H. Weiman, "Titanium Corrosion in Aqueous Solutions," Corrosion 22, 98-106 (1966).

7. H. P. Godard, W. B. Jepson, M. R. Bothwell, and R. L. Kane, The Corrosion of Light Metals, Wiley, New York, 1967, pp. 327-33.

8. J. A. Beavers (Battelle Columbus Laboratories), personal communication to J. C. Griess (Oak Ridge National Laboratory), July 1980.

9. J. E. Truman, "Factors Affecting the Testing of Stainless Steel in Concentrated Nitric Acid," J. Appl. Chem. 4, 273-82 (1954).

10. M. A. Streicher, "General and Intergranular Corrosion of Austenitic Stainless Steels," J. Electrochem. Soc. 106(3), 161-80 (1959).

11. J. S. Armijo, "Intergranular Corrosion of Nonsensitized Austenitic Stainless Steels," Corrosion 24(1), 24-30 (1968).

12. A. B. McIntosh, "Corrosion Problems in Nuclear Power Production," Chem. Ind. 687-92 (June 1, 1957). 